Governmental financial resilience under austerity in Austria, England and Italy: how do local governments cope with financial shocks?

by

Carmela Barbera (The Catholic University of the Sacred Heart, Milan and SDA Bocconi School of Management)

Martin Jones (Nottingham Business School)

Sanja Korac (Alpen-Adria University, Klagenfurt)

Iris Saliterer (Freiburg University)

Ileana Steccolini (Newcastle University London)

Contact author: Ileana Steccolini ileana.steccolini@newcastle.ac.uk 


\title{
Governmental financial resilience under austerity in Austria, England and Italy: how do local governments cope with financial shocks?
}

\begin{abstract}
The recent economic and fiscal crises provide an opportunity for learning lessons of general and practical relevance into how governments face shocks affecting their financial conditions. This article draws on the resilience concept to investigate the organizational capacities that are deployed and/or built by local governments (LGs) to respond to such shocks, looking at their combinations and interactions with environmental conditions. The paper presents the results of a multiple-case analysis of 12 European LGs across Austria, Italy and England. The analysis allows to highlight and operationalize different patterns of financial resilience, i.e. selfregulation, constrained or reactive adaptation, contented or powerless fatalism, that are the result of the interaction and development over time of different internal and external dimensions.
\end{abstract}

\section{Introduction}

Governments throughout the world have been challenged by the recent economic and fiscal crises. An increasing number of contributions have explored governmental responses to what has become commonly referred to as 'the crisis' (Kickert 2012a, 2012b, 2013; Lodge and Hood 2012; Peters 2011; Peters et al. 2011; Pollitt 2010), often focusing on austerity, decline and cutback management (Kickert 2012a; Posner and Blöndal 2012; Raudla et al. 2013). Surprisingly fewer studies deal with the long-term strategic and managerial consequences of such phenomena for public organizations (Bozeman 2010; Pandey 2010; Pollitt 2010) or the processes and capacities which allow them to respond to crises. Along these lines, calls have emerged to develop crisis research, with attention to the skills and capacities required to cope 
with crises (Boin and Lodge 2016). This article responds to this scholarly call and practical need by drawing on the concept of resilience. Looking at Local Governments (LGs), it explores the multiple facets of governmental financial resilience, i.e. governments' ability to anticipate, absorb and react to shocks affecting their finances over time. In doing so, the paper identifies the internal and external dimensions and capacities that shape governmental financial resilience, and sheds light on how their interaction gives rise to different resilience patterns.

In order to capture the organizational processes and capacities behind governmental responses to the crisis, 12 case studies across Austria, Italy and England are analysed. The country settings represent different administrative traditions (Meyer and Hammerschmid 2010; Pollitt and Bouckaert 2011) and different financial vulnerabilities (see Lodge and Hood 2012), providing evidence that, if some processes and dynamics may be specific to the country settings or dependent on environmental conditions, at the same time similar resilience patterns can be identified across countries, depending on how external conditions and internal capacities intertwine over time. Though the study is placed in the context of a financial crisis and its aftermath, the aim of the paper is not to look at country-level, or specific, responses to the crisis. Rather, the variety of cases and countries under analysis allows to highlight and operationalize patterns of behaviors of more general relevance to public management and resilience literature.

The article is structured as follows. The next section provides a review of the current literature on financial and organizational responses to shocks. Section three discusses resilience and highlights the purpose and main research questions of the paper. The fourth section specifies the methods. The results are presented in the fifth and sixth sections, with the former focusing on the emerging analytical framework and dimensions of resilience, and the latter on the patterns of resilience emerging from the analysis. Section seven discusses the findings, and the final section draws the conclusions and implications for research and practice. 


\section{Responding to financial shocks and crises: adopting a resilience perspective}

\section{Responding to shocks}

The recent crisis has brought about a resurgence of interest in governmental fiscal stress and organizational reactions to shocks. On the one hand, financial management literature has seen in the crisis an opportunity for reviving the long-standing academic interest in decline and cutback management (Hood and Wright 1981; Levine 1978, 1979; Levine and Posner 1981; Schick 1980). Studies of how governments tackled the crisis and austerity have been developed in the aftermath of the crisis (Cepiku et al. 2015; Kickert 2012a, 2012b, 2013; Overmans and Noordegraaf 2014; Raudla et al. 2013; Scorsone and Plerhoples 2010; West and Condrey 2011), most of them contributing to an accumulation of contextual knowledge on fiscal and organizational response strategies by providing detailed and rich accounts and classifications of governmental reactions. Fewer studies also take an explanatory stance, looking at the role of organizational and/or contextual factors in affecting such reactions (Cepiku et al. 2015; Hendrick 2011; Jimenez 2012, 2014; Maher and Deller 2007; Overmans and Timm-Arnold 2016), while generally paying less attention to explaining how these factors influence each other over time, thus leaving governments more or less vulnerable to the next crisis.

The crisis has also revived research focusing on the effectiveness of organizational reactions to shocks and turbulences (e.g. Boyne 2006, Boyne and Meier 2009a, 2009b; Meier and O' Toole 2009; Meier et al. 2010; O' Toole and Meier 2010). This predominantly quantitative research stream highlights the role of organizational capacities, but has pointed to the need to further explore them in more depth and over time (Bettis and Hitt 1995; Boyne and Meier 2009a; Meier and O' Toole 2009), i.e. to explore how organizational capacities are not only 
deployed to cope with shocks, but also evolve and interact with environmental conditions before, as well as as a consequence of such shocks.

In light of these considerations, the recent financial crisis provides fertile ground for addressing these aspects and learning new lessons by adopting a long-term view (Bozeman 2010). This study uses the perspective offered by resilience (Davoudi et al. 2013; Suttcliffe and Vogus 2003) to contribute to enrich and integrate the insights coming from the above streams of literature on how governments deal with financial shocks and disturbances over time. A resilience perspective not only captures organizational processes behind governmental responses to crises from a long-term perspective, but also draws attention to the interaction of external factors (environmental conditions) and internal factors (organizational dimensions) and illuminates their role in dealing with shocks and shaping related vulnerabilities (Shaw 2012; van der Vegt et al. 2015).

\section{Adopting a resilience perspective}

Resilience has experienced an increasing transfer to social sciences (e.g. Davoudi et al. 2013; Linnenluecke 2015), though with a diversity of perspectives. The engineering perspective on resilience refers to the ability of an organization to reduce risks and resist, or quickly recover from crises (Boin and Van Eeten 2013; Holling 1973; Pickett et al.2004; Shaw 2012; Sutcliffe and Vogus 2003; Vickers and Kouzmin 2001). This view focuses on recovery, robustness under enormous stress, and the ability of bouncing back to an original state (Altintas and Royer 2009; Bhamra et al. 2011; Boin and McConnell 2007; Boin and Van Eeten 2013; Coutu 2002; Davoudi 2012; Duit 2016). Under this perspective, financial and personnel capacity, and the activities of an organization, are aimed to build slack that cushion and absorb shocks (Huy and Mintzberg 2003; Meyer 1982) to ensure survival. The evolutionary perspective on resilience 
(Davoudi 2012; Hamel and Välikangas 2003; Pike et al. 2010) emphasizes the capacity to reorganize as a response to, or in anticipation of, disturbances (Martin and Sunley 2006) and to "keep operating even in adverse 'worst case' conditions and to adapt rapidly in a crisis" (Hood 1991, p. 14). In this view, organizations become resilient not despite of distress or decline, but in anticipation or because of it (Sutcliffe and Vogus 2003). Here, resilient organizations recognize a window of opportunity in disruptions and alter or reinvent their strategies ('bounce forward') before circumstances force them to do so (Gunderson and Holling 2002; Hamel and Välikangas 2003; Holling 1986).

The above considerations suggest that the resilience concept has different definitions, thus calling for further explorations aimed at identifying whether different forms of resilience can be observed empirically.

Not only is resilience multifaceted, but in the literature it is also shown to be the result of a variety of dimensions (Darnhofer 2014; Linnenluecke 2015). Some authors focus on anticipation and awareness of risks (Lengnick-Hall and Beck, 2005; Somers, 2009; Linnenluecke and Griffith 2013; see also Boin et al. 2010, p. 7 and Boin and Lodge 2016, ), or situation awareness (McManus et al. 2007), ie, the extent to which an organization has a clear understanding of the environment and is able to manage key vulnerabilities. Other authors have highlighted the capacity to cope with unanticipated shocks once they manifest themselves (Wildavsky 1988, p. 88) and to quickly resume crucial functions (Boin 2016), as well as adaptive capacities, ie, the set of available resources and competencies that allow persistence, adaptation and transformation in the face of disturbances (e.g. Davoudi et al. 2013; Darnhofer 2014; Linnenluecke and Griffith 2013; Nelson et al. 2007).

In the above mentioned literature, resilience dimensions are discussed in broad terms, with a variety of meanings and mostly from a normative perspective. As such, there is no general agreement on how different dimensions shape resilient behaviour (Linnenluecke 2015). Indeed, 
there have been calls in the public administration literature for empirical studies to give more depth on the different dimensions of resilience (Boin and Lodge 2016; Boin and Van Eeten 2013; Duit 2016). This would also require exploring their combination and interactions over time, and how these affect overall resilience.

Since the recent crisis offers the possibility of studying multiple cases of local governments reacting to it, it is possible to reach a finer grained view both on reactions to the crisis, and on resilience patterns, by looking at how resilience can be shaped by various dimensions and conditions. In light of these considerations, this study aims to explore the multiple facets of financial resilience, i.e. governments' ability to anticipate, absorb and react to shocks affecting their finances over time. In doing so, and trying to address the above gaps, it is aimed at (i) identifying the internal and external dimensions and conditions that shape financial resilience; (ii) exploring if their development and interaction over time gives rise to different resilience patterns; (iii) better understanding how capacities evolve, i.e. are deployed and developed, and interact in anticipation or in reaction to crises over time.

In addressing these aims, reliance on resilience literature allows to add new insights on the role of the interactions of environmental conditions and internal capacities and conditions in shaping such actions and reactions over time. At the same time, the paper enriches resilience literature by identifying and operationalizing the relevant dimensions of financial resilience.

\section{Methods}

\section{Research design}

Given the aim of the paper mentioned above, a case study design appears to be particularly suited for connecting theory and empirical evidence (Yin 2009). This approach allows the exploration of phenomena emerging from the data, while at the same time embracing useful 
concepts that have been discussed in prior literature (Glaser and Strauss 1967; Suddaby 2006; see also Denis et al. 2001; Edmondson et al. 2001; Ridder et al. 2006).

The analysis is based on a multiple-case study of 12 European LGs across Austria, Italy and England. The next subsections further explain the choices regarding the context of the analysis, the selection of cases, and data sources and analysis.

\section{The context: European LGs}

The variety of European countries' administrative traditions (Hesse and Sharpe 1991; Meyer and Hammerschmid 2010; Pollitt and Bouckaert 2011), financial vulnerabilities (Lodge and Hood 2012) and reactions to the global financial crisis (Lodge and Hood 2012; Peters 2011) allows the adoption of a 'most different/most dissimilar' approach (Przeworski and Teune 1970) in the selection of countries (Hesse and Sharpe 1991; Kuhlmann 2010; Wolman 2008).

Thus, Austria was chosen as a country belonging to the Continental European administrative tradition and with medium financial vulnerability before and after the crisis; England as an example of the Anglo-Saxon tradition and of a country with low financial vulnerability before the crisis, and high after it; and Italy as Southern European country, and one with high financial vulnerability before the crisis and medium after it. The most relevant differences across the three countries are summarized in table 1 in the appendix, which present their main features in terms of administrative tradition and intergovernmental fiscal relationships.

\section{Case selection}

The case selection targeted LGs which show similar administrative responsibilities and functions in their respective countries. In Italy these were seats of province, in Austria seats of district authorities and in England single-tier and county councils (STCC). 
A theoretical sampling approach in three steps was adopted (Patton 2015; Neumann 2006, p. 224; Eisenhardt 1989; Eisenhardt and Graebner 2007), whereby the cases were 'chosen to fill theoretical categories' (Eisenhardt 1989, p. 537). The first step required the definition of possible categories of cases through the identification of key variables to be represented. Given the aim to explore how governments deal with shocks in their finances over time, long-term measures of financial performance were considered. The criteria for selection were thus identified in the average financial performance and its volatility over ten years (2002-2011). The conventional measure of governmental financial performance is the budgetary position, which has traditionally been expected to be kept around zero (Bretschneider and Gorr 1992; Rose and Smith 2011) as local governments are often legally required to balance the budget at the end of each year ${ }^{1}$.

In the second step, LGs were classified in terms of their combination of average budgetary position and volatility. This allowed to identify main groupings of cases, representing common and at the same time polar combinations across the countries: low volatility and a budgetary position around zero, high volatility and negative or positive, as well as around-zero budgetary positions. Other combinations were much less likely to occur (i.e. negative or positive budgetary position and low volatility) and were thus not included in the analysis.

In the third step, one case for each of these four combinations of budgetary position and related volatility was selected for each country, leading to a total of 12 cases. Table 2 in the appendix provides financial data on the selected cases, covering functions and revenue structure of LGs.

\footnotetext{
${ }^{1}$ For Italy and Austria, that adopt a commitment based method of accounting, the budgetary position measure is represented by the variation in the commitment-based surplus/deficit position. For England, where a modified accruals basis of accounting is adopted, the measure is represented by the contribution to unallocated reserves as it represents the "balancing figure" between the net budget requirement on the one hand and government grants and locally collected taxation on the other. In England expenditure is reported net of direct income and service specific government grants, and is presented as balancing with the main non-specific sources of income (general government grants, local taxation and contributions to/from reserves).
} 


\section{Collection of data and analysis}

30 semi-structured interviews served as the cornerstone of the case study (Yin 2009), but triangulation of informants (up to three interviewees per case) and of data sources were relied upon to corroborate the collected information (Bailey 2007). Document analysis of audit and media reports, and in particular the analysis of the respective LG financial documents, was used to validate statements. The selection of the interviewees identified those individuals who have relevant information on financial issues. In particular, chief executive officers and financial directors were interviewed in all the cases (except one where the officer was not available). Additional interviews with service directors were conducted in 3 Italian cases and 3 English cases. In the majority of cases (26 of 30) the interviewees had been working in the respective local government for more than 10 years.

The interviews, were carried out between January 2013 and November 2015. The interviews lasted between 45 and 90 minutes and included open-ended questions on the financial health of the LG, its main financial and non-financial goals, the main risks and shocks faced by the LG, and how LGs had identified and responded to them.

Given the nature of crises and subsequent limitations to ex-ante research designs, case studies were carried out ex-post and as such reconstruction of events could be influenced by interviewees' ex-post rationalization (Patton 2015; Trochim and Donnelly 2006). Considering the aim of the study, ex-post rationalization is to be seen as helpful as, while in the short term developments may appear blurred, an ex-post approach offers clearer insights into multidirectional relationships (Pettigrew 1990). This may be especially true in this case, as resilience and its inherent dimensions are often described as becoming observable over time (Linnenluecke 2015) and visible under a particular set of exceptional circumstances. 
From the interviews major themes emerged, which were discussed during debriefing sessions among the researchers and compared again with the empirical materials as well as with extant literature. This allowed the initial emergence of broad dimensions of resilience, which were further refined, developed and detailed into new and more focused categories through continuous iteration between the case data and extant literature (Eisenhardt and Graebner 2007; Stewart 2012). First, in each country the data were coded and classified according to the broad themes and categories that emerged during the data collection and then compared and aligned across countries. These categorizations were further compared with contributions from the literature streams discussed above, and coding schemes were revised. The final coding categories and their relationships were examined to identify underlying patterns and reach the final conceptualization of financial resilience. Table 3 in the appendix presents the main variables that emerged from the analysis, their definitions and typologies, as well as how they were operationalized. It also shows how the interviews were coded, providing examples of quotations for each variable.

\section{Exploring financial resilience: dimensions and patterns}

\section{Emerging dimensions of financial resilience: the framework}

This section presents the main dimensions of financial resilience emerging from the analysis (see also table 3 appendix). The framework that emerged from the iteration process described above revealed that LGs' financial resilience, i.e., their ability to anticipate, absorb and react to shocks affecting their finances, was the result of the interaction of environmental conditions as well as organizational dimensions over time, as shown in figure 1.

(Figure 1 here) 
The environmental conditions, encompassing economic, institutional and socio-economic contextual features, emerged as relevant from the interviews in shaping perceived financial vulnerabilities and capacities. The most relevant external shocks quoted by the interviewees were all related to the crisis and its consequences.

Two main categories of capacities for facing shocks emerged from the analysis: anticipatory and coping capacities. Anticipatory capacities refer to the availability of tools and capabilities that enable LGs to better identify and manage their vulnerabilities and to recognize potential financial shocks before they arise, as well as their nature, likelihood, timing, scale and potential impacts. In this regard, anticipatory capacity is not limited to the presence of systems in place to plan, control, and manage risks, but also related to situation awareness and sense-making (e.g. Boin et al. 2010; Lengnick-Hall and Beck 2005; Linnenluecke and Griffith 2013; Mcmanus et al. 2007, Somers 2009; Weick and Suttcliffe 2009). Coping capacities, which lie dormant in times of order and become visible in times of disruption through coping actions (Linnenluecke 2015), refer to resources and abilities that allow shocks to be faced and vulnerabilities to be managed. Coping capacities can take different forms: buffering capacities represent the ability to absorb the impact of a shock without changes in its structure or function; adapting capacities refer to the ability to implement incremental changes to extant structures and functions without changing underlying principles, culture, and values; transforming capacities, in turn, comprise the ability to implement radical changes, characterized by changes in the structure, function, goals and values of the organization (see also Béné et al. 2012; Darnhofer 2014; Davoudi et al. 2013; Folke et al. 2010).

In general terms, vulnerability represents the exposure to shocks (Hendrick 2011; McManus 2007). Indeed, LGs' financial vulnerability, as perceived by organizational actors, was discussed as being the result of both external (e.g. dependency on grants, undiversified revenues) as well as internal (e.g. debt financing, reserves) sources, and thus turned out to be 
at the interface between the environment and the organization. Rather than an objective measure of vulnerability, it is the perceived vulnerability, which turned out as central in understanding patterns of financial resilience (see also Jimenez 2012; Maher and Deller 2007, 2011). The roles of the above dimensions are further discussed in the next section.

\section{Emerging patterns of resilience}

The interaction of the above conditions and dimensions gave rise over time to different patterns of financial resilience: self-regulation, constrained or reactive adaptation, contented or powerless fatalism. These patterns are discussed in the next sub-sections. Appendices 2-4 sum up, for each LG, how the environmental conditions and organizational dimensions and related perceived vulnerabilities combined to give rise to these patterns.

\section{Self-regulators: A1, E1, E2, I1}

The LGs in this group (A1, E1, E2 and I1), generally show low levels of financial vulnerability, high anticipatory capacities and comprehensive coping capacities over time (table 4 in the appendix). Anticipatory capacities in these LGs relied on well-developed control and planning systems, used for predictions and simulations, and careful creation of reserves. These features appeared to originate in a strong willingness of keeping potential risks under control.

'What we have done over the last decade is to move much more towards a 3-year budget strategy. We started that during the good times and it became even more important [...] in times of austerity.' (CEO, E1)

'It is the administration's responsibility to warn in time. [...] the signals were there... and our financial director was the one who was planning with lower revenue shares - intentionally [...] to have a cushion of about 15 per cent.' (CEO, A1)

'We try to make good predictions, [...] through careful monitoring. The budget is [...] constantly reviewed during the year.' $(C E O, I 1)$ 
These LGs succeeded in developing and using coping capacities which addressed their vulnerabilities. Although they used near-term buffering capacities to cope with the crisis, they also relied on adaptive and transformative ones.

For example, I1 increased networking with external stakeholders in providing services. A1 strengthened its self-sufficiency through re-structuring and collegiate planning, hiring people with professional knowledge, enhancing internal competencies, and generating alternative income sources. E1 had embarked on a path of "earned autonomy" and developed a "selfsustaining financial base" which was viewed as a source of strength through the austerity period, while E2 realized early on that it needed to increase locally-derived fiscal income by attracting new businesses and new housing developments.

These LGs aspire to maintain a status of self-sufficiency and self-regulation, avoiding being (too) reliant on funding or regulation from upper government levels, through continuous anticipation of, and active adaptation to, external shocks. This self-regulatory pattern of resilience is found in all the three countries (A1, E1, E2, I1), suggesting that it may be desirable to effectively manage environmental conditions, shocks and challenges. This is also reflected in generally low and stable levels of perceived vulnerability over time.

'We [...] are one of the Italian Municipalities with the lowest level of debt [...].' (CFO, II)

'If you look at our balance sheet you will see that it is extremely healthy in terms of sitting on reserves and cash levels.' (CFO, E1)

'We have the lowest debt level in the state, probably. [...] our guiding principle has always been to build reserves for rainy days.' (CEO, A1)

The above cases show that the willingness to maintain or enhance self-sufficiency encouraged a strong investment in comprehensive anticipatory capacities, adapting and transforming capacities, which ensure a tight control on both external and internal sources of financial vulnerability. Interestingly, three of four cases in this pattern share similarities in that their 
average budgetary position remained consistently around zero over a ten-year period.

\section{Constrained adapters: E3, E4}

The LGs in this group (E3 and E4) generally showed high anticipatory capacities and deployment of buffering and adapting coping capacities, but witnessed an increase in perceived financial vulnerability over time (table 5 in the appendix). It was relatively low when the crisis hit, reflecting a belief that strong anticipatory capacities would make them capable of withstanding disturbances.

'We have a corporate risk approach, [...] so we have a corporate risk register.' (CEO, E3)

'[E4] was always well run, we always had plenty of reserves and were well-financed.' (CEO \& CFO, E4)

This gave the crisis a prominent place in decision-making, prompting the taking of early action, and the deployment of coping capacities. Also, it encouraged the creation of reserves, subsequently used both as buffers and as levers to assist and promote change as well as absorb slippage.

These LGs appear to perceive the environment (weak financial opportunities, complex social needs and dependence on central government funding) and the financial shocks as constraining, reflecting a limited ability to cope with external challenges. This left them more dependent on central government resources or decisions and was also reflected by a use of coping capacities focused more on buffering and adapting actions, including efforts on managing internal resources through reducing expenditure, rationalizing services, managing demand and increasing efficiency.

'[E4] is not the most affluent of areas, so we don't have a lot in terms of council tax yield...we struggle in terms of inward investment and business [rates]' (CEO \& CFO, E4) 
'We were not always positioned well in terms of opportunities for finances [...] We have some very affluent and some very deprived areas...' (CEO, E3)

This suggests that they perceive their sources of vulnerability as being more out of their hands. The interviews also revealed a sense of doom regarding the uncertain nature of the future outlook.

'If it goes on, what can we deliver in 2016? [...] no one knows how the financial outlook is going to be [...]. Some people are talking about the same level again, but that's just not sustainable with the current breadth of services...' (CEO \& CFO, E4)

'We made the first couple of years of cuts without really impacting significantly on services, people didn't see a difference [...] but it is about stopping doing things now, or doing things differently.' (CEO, E3)

\section{Reactive adapters: $A 2$ and 14}

The LGs in this group (A2 and I4) were characterized by high vulnerability and limited anticipatory and coping capacities when the crisis hit. However, while the crisis has magnified perceived vulnerability, it also appears to have triggered a reorientation path towards a strengthening of both capacities (table 5 in the appendix).

After the crisis, A2 experienced budget deficits for three years due to unstable and undiversified revenues sources, high debt financing and strong reliance on grants. I4 seemed to be on the brink of default due to high debt financing, past reliance on one-off revenues which, after the crisis, fell short, and to the low degree of control on external subsidiaries.

'[...] the economic crisis was a massive slump for us. This was also the reason why we operated with losses for three years. [...] There was a drop in grants. And personnel cuts in businesses and also drops in municipal taxes. [...] This was massive, going into millions.' (CFO, A2) 
'The first goal was to reduce significantly high debts, and then securing the municipal budget. In 2012 we were talking about financial collapse. ' $(\mathrm{CEO}, \mathrm{I4})$

In A2, the interviewees recognized a virtual absence of anticipatory capacities, and in I4, planning of activities and the identification of goals were weak.

'The economic crisis [...] caught us unprepared. '(CFO, A2)

After the crisis, both LGs started to invest in building the capacities aimed to address their respective vulnerabilities. In particular, A2 perceived the crisis as critical immediately after its occurrence, and hence implemented long-term investment planning and scenario analysis, and buildt and deployed coping capacities.

'We reduced subsidies, personnel costs; on the revenue side, we searched for possibilities with corrections of fees; those were the first measures taken, they can be implemented immediately... [...] reduced service standards in the area of roads and works, parks, and so on. And then we tried to tackle the structural problems and challenges [...] we did a task review, audited the standards [...] we also did a structural school reform.' (CEO, A2)

With some time lag, I4 took a similar approach. In 2011, the extraordinary commissioner appointed after the resignation of the mayor increased all taxes, while undertaking rationalization. This translated into a strengthening of monitoring tools, investments in new models for delivering services, increased networking with external stakeholders, and, thus, an overall expansion of anticipatory and coping capacities.

'They [the department for social services] have changed the way they manage services to ensure that the $L G$ becomes a facilitator of relations, a point of collection of resources from the territory.' (CFO, I4)

Strengthening their initially low anticipatory and coping capacities, A2 and I4 appear to have 
embarked upon a path of reactive adaptation. Notwithstanding their challenging institutional and economic environment and the impact of shocks (for both a decrease in revenues, with lower taxes and grants for A2 and a tightening of fiscal targets and increased regulatory uncertainty in I4), the interviewees felt they were in the position to address their vulnerabilities. Moreover, they perceived the crisis as the trigger to bring about changes as well as an opportunity to (re-)gain control over their financial vulnerabilities.

\section{Contented fatalists: A3 and A4}

The fourth group includes two Austrian LGs (A3, A4) that are wealthy and were not initially perceived as particularly vulnerable, mainly thanks to a high, stable and diversified ownrevenue base, but whose perceived vulnerability increased after the crisis (table 6 in the appendix).

'Luckily we have financially strong businesses that pay a lot of taxes.' (CFO, A4)

'We have many small and medium sized enterprises, and therefore we did not have such an impact on the municipal tax [...].' (CFO, A3)

Anticipatory capacities in these LGs were initially weak as they were not seen as necessary. In A3, investment in anticipatory capacities (e.g. anticipated approval of supplementary budget, quarterly information on financial condition) was made after the crisis, however the coping capacities deployed (mainly buffering, e.g. cost cuts, deferring investments) did not address emerging vulnerabilities, mostly related to an ageing population.

'The crisis hit us and while we had planned to generate increasing revenues, we had to increase the debt level to finance investments. When the crisis occurred in 2007/2008, we immediately tried to reduce our spending, $[\ldots]$ to defer investments or maintenance...' (CFO, A3)

A similar pattern can be observed in A4, where favorable environmental conditions may have 
encouraged the LG to downplay emerging vulnerabilities, while not investing in anticipatory and coping capacities.

'...risk monitoring, assessment... this does not exist [...] During investment projects there is always information that the projected budget might not be enough.' (CEO, A4)

'We are still healthy I would say, but a stronger wind would blow us away. [...] we do have high debt at this time and we aim to reduce it.' $(C F O, A 4)$

In short, A3 and A4 appear to behave like contented organizations, which, resting on their laurels, had not anticipated the crisis, and hope to weather the storm relying on buffering capacities. In the long term, however, this may translate into increased vulnerability and the need to take stronger actions. The still wealthy conditions and context have so far offset extant anticipatory and coping weaknesses.

\section{Powerless fatalists: I2 and I3}

The fifth group includes two Italian LGs (I2 and I3) characterized by initial high vulnerability (e.g., high burden of debt repayment and doubtful liabilities ${ }^{2}$ ), a sense of powerlessness in the face of the crisis and limited anticipatory capacities. Relying mainly on buffering and postponing critical issues to the future, they both experienced an increase in their perceived vulnerability after the crisis (table 6 in the appendix). Low anticipatory capacities are reflected in weak monitoring and planning mechanisms.

\section{'[...] information flows often do not occur in real time' (CFO, I2) \\ 'We do not have [...] an office for management control' (CFO, I3)}

\footnotetext{
${ }^{2}$ Doubtful liabilities are liabilities of doubtful recovery.
} 
Coping with the crisis was dominated by deploying buffering capacities, ranging from cost cutting to deferring investments in both LGs, reliance on selling assets (I2), and building of financial reserves from a one-off transaction (I3) made in 2008 with a subsidiary company.

'Certainly we think about the capacity to have sources of revenues. [...] Among the alternatives, there is selling assets [...]' (CEO, I2)

'What determines recent years' surpluses is a very large surplus, around 10 million, established in 2008. It comes from a granting credit made to a subsidiary for the purchase of some municipal buildings...' (CFO, I3)

Of particular relevance was the belief of not being able to react to the crisis and the higher legislative uncertainty that characterized Italy in its aftermath. The financial crisis and its consequences seemingly exceeds the threshold of existing capacities, leading to a perception of powerlessness and forcing these LGs to a day-by-day management of emergencies, highly reliant on buffering capacities.

Although the interviewees declared that they were starting to improve their anticipatory capacities by increasing monitoring, a short-term perspective prevailed and the increased uncertainty appears to translate in a higher level of vulnerability after the crisis.

'We have tried to live year-to-year, not to say almost day-to- day.' $(\mathrm{CFO}, \mathrm{I3})$

'The General Development Plan represents our attempt to plan activities, but it clashes with the reality of the decline of certain annual revenues [...]. We are often forced to postpone activities. Imminence and urgency affect the quality of programming.' (Service Director, I2)

This suggests a fatalist type of resilience, externally driven, constrained by external pressures and limited reliance on internal capacities. This combination supports a vicious circle, whereby the limited capacities feed vulnerability and the perception that the latter cannot be controlled may, in turn, discourage investment on capacities. 


\section{Discussion}

This study set out to explore the internal and external dimensions and conditions that shape financial resilience in the aftermath of the global financial crisis, identify the different resilience patterns they give rise to, and how such dimensions develop and interact in anticipation or in reaction to crisis over time. In doing so, it provides a first conceptualization and operationalization of governmental financial resilience.

Looking at the emergent dimensions of resilience, the above analysis adds to previous literature by offering a view not only on organizational responses to shocks, but also on the roles of the environmental conditions, types and combinations of organizational capacities, and actors' perceptions in shaping how local governments face shocks and crises. More specifically, the above analysis provides evidence of the how anticipatory and coping capacities as well as perceived financial vulnerability contribute to explain the emerging patterns of financial resilience, offering an in-depth operationalization of such capacities and patterns.

Looking at emerging resilience patterns, the findings presented above show that the interaction of these dimensions gave rise to different patterns of financial resilience: self-regulation, constrained or reactive adaptation, contented or powerless fatalism. The findings provide a rich view of these typologies of LG financial resilience, corroborated by the multiplicity of cases and shown in the Appendices to the paper. This adds to existing literature on responses to crises, by proposing a novel typology that is not only based on responses, but also on how the responses are shaped by existing external conditions and internal dimensions. It also responds to recent calls for exploring the diversity of approaches to resilience (Duit, 2016).

In looking at how the combination and interaction of different resilience dimensions can explain emerging resilience patterns, the analysis suggests that a more balanced view is necessary to understand such patterns, integrating the literature that emphasizes the importance 
of environmental conditions in affecting governments' behaviors (Boyne and Meier 2009; Hendrick 2011; Linnenluecke 2015) with the resilience literature looking at internal capacities reviewed above.

Examples of this need were evident in each of the three countries. In England, it seems that the institutional environment may have affected LGs anticipatory capacity. There, according to the interviewees, the managerial reforms implemented over the last few decades may have fostered and institutionalized high anticipatory capacity, thus contributing to equipping the investigated LGs to anticipate possible shocks. However, this alone could not explain the different - selfregulatory and constrained adapters - resilience paths in this country. More specifically, these cases show the importance of coping capacities in addressing environmental conditions and managing emerging vulnerability over time. In Italy, the re-centralization of decisions, constantly changing central regulations on revenues and transfers, as well as difficult economic conditions were mentioned as limiting in all cases. However, this resulted in low anticipatory capacity and limited coping capacities (mainly buffering) and higher vulnerability in two LGs only (powerless fatalists). The other two tried to keep their vulnerability under control either by developing, or by keeping their anticipatory capacity high and deploying at least selective coping capacities (self-regulatory and adaptive resilience). For Austria, the relatively stable policy and regulatory framework together with low monitoring requirements, and the relative economic affluence of local economic conditions appeared to be the reason for low anticipatory capacity and mainly limited coping capacities (mostly buffering) in two cases (contented fatalist resilience). In contrast, the other two show patterns of self-regulatory and adaptive resilience that are similar to the respective English and Italian cases mentioned above.

The analysis also revealed that, while anticipatory, adaptive, and transformative capacities are complementary and appear to reinforce each other, reducing perceived financial vulnerability, heavy exploitation of buffering capacities may crowd out the development of other capacities 
needed to bounce forward, resulting in higher levels of vulnerability over time (Davoudi et al. 2013; Meier and O’Toole 2009; Wildavsky 1988).

Finally, this study highlights that not only 'objective' conditions matter, but also how such conditions are identified, understood, and managed (see also Boin et al. 2010; Lengnick-Hall and Beck,2005; Linnenluecke and Griffith 2013, Lu and Xue 2016; McManus et. al. 2007; Somers 2009; Weick and Suttcliffe 2009). This points to the major role played by the perceived sources of vulnerability in explaining patterns of resilience. The LGs' financial vulnerability was discussed as being the result of both external (e.g. dependency on grants, undiversified revenues) and internal (e.g. debt financing, reserves) sources influencing the LGs' exposure to financial shocks, and thus turned out to be at the interface between the environment and the organization, and central in understanding patterns of financial resilience. The across-case analysis revealed that - more than a specific level of vulnerability (Hendrick 2011) - the 'endogenization" of vulnerability (i.e. the sense of being able to influence its sources) or its 'exogenization' (i.e., the sense of being unable to control its sources) affected the way in which the financial crisis and the resulting impacts were interpreted, and received attention. At one extreme, the sources of financial vulnerability were regarded as at arm's length and thus manageable. This was the case among the self-regulators, where strong and comprehensive investment in anticipatory and coping capacities increased the ability to manage or offset the impact of environmental conditions. In this case vulnerability was kept under control.

At the other extreme, the sources of vulnerability were generally attributed to the overall environment and scant consideration was given to the development of internal capacities. This resulted either in powerless behaviors, where the environment was seen as so uncertain and unfavorable that the possibility to keep vulnerability under control was not considered a viable option, and only buffering capacities were relied upon; or in contented behaviors, where favorable environmental conditions seemingly made it less urgent to invest in anticipatory and 
coping capacities. Both patterns exerted a passive behavior towards their vulnerability sources (i.e. 'exogenization' of vulnerability) and an increase in vulnerability was shown. The two extremes suggest the existence of respectively a virtuous and a vicious circle. In the middle between these extremes, there are those LGs where vulnerability either increased (i.e., cases where anticipatory and coping capacities did not target the specific environmental sources of vulnerability that emerged after the crisis, such as constrained-adaptive patterns) or decreased (i.e., cases where the shock represented an opportunity to invest in capacities to re-gain ownership of vulnerability, such as reactive-adaptive patterns). Indeed, it can be expected that in regaining ownership of their vulnerability, these LGs may be able to adapt and progress in time to positions of self-regulation, or may ultimately find they are constrained in the extent to which they can manage sources of disturbance in the environment. This analysis suggests that explaining resilience patterns requires taking into account whether LGs endogenize or exogenize their sources of vulnerability.

The above reflection also contributes to explain why it was not always possible to identify a direct and straightforward link between resilience patterns and the financial data used to select the LGs. The results show that specific combinations of budgetary position and volatility do not necessarily lead to specific resilience patterns. This link could only be observed in the selfregulatory group (A1, E1, I1), where average budgetary position remains consistently around zero over the ten-year period. In contrast to other resilience patterns, self-regulatory resilience seems to be related to a strong orientation towards maintaining a stable financial position even after adjusting for shocks. However, where volatility is higher and the budgetary position is different from zero, this link disappears and mere financial data are not sufficient to understand emerging patterns of resilience, requiring to take jointly into consideration environmental conditions and internal capacities and a central role is played by perceived vulnerability. 


\section{Conclusion}

The increased uncertainty, volatility and complexity under which LGs operate, coupled with significant reductions in public spending, have put great emphasis on how they cope with shocks, especially financial ones. This article has explored governmental resilience, i.e. governments' ability to anticipate, absorb and react to shocks affecting their finances over time. In doing so, different patterns of financial resilience (i.e. self-regulation, constrained or reactive adaptation, contented or powerless fatalism) have been identified, and internal and external dimensions that shape these patterns have been traced out. The perspective of resilience proved useful in integrating contributions from different streams of literature and to analyse the deployment and development of internal capacities of governments in dealing with uncertainty related to shocks and disturbances (Davoudi 2012; Linnenlucke and Griffith 2010; MamouniLimnios et al. 2014; Shaw 2012; Sutcliffe and Vogus 2003; Weick and Sutcliffe 2007). This approach therefore provides insights of more general and long-term relevance on how LG financial resilience is shaped by environmental conditions, organizational dimensions (anticipatory and coping capacities), and financial vulnerability that results from and influences the interplay of the former two.

Though the study is placed in the context of a financial crisis and its aftermath, and looks at three countries, the variety of cases and countries under analysis allow to highlight and operationalize patterns of behaviors that can be seen as being of more general relevance to the literature.

The study provides evidence that environmental conditions, often highlighted in contributions on fiscal stress and austerity, are not sufficient per se to explain different resilience patterns and to ensure resilience-building processes, which require serious consideration and development of organizational (anticipatory and coping) capacities. At the interface between environmental conditions and organizational capacities lies perceived financial vulnerability, 
which is at the same time the consequence of their interaction over time, as well as an important explanation of resilience patterns. This study therefore provides support to the view that it may be necessary to go beyond country-based characterizations of public sector organizations, especially at the local level, and that it is necessary to take a finer-grained view on how the environmental and organizational features shape financial resilience.

The analysis can have relevant implications for practitioners and policy makers alike. From the point of view of policy makers, this study highlights the role of centrally-defined policies for LGs, in inhibiting or enhancing anticipatory and coping capacities as well as influencing perceived financial vulnerability. More specifically, regulators may encourage the creation, or even require, mandatory reserves to use as a countercyclical tool, while fostering revenue diversification and fiscal autonomy. At the same time, the analysis suggests that public managers should not only look at the external environment and nationally imposed policies to prepare for or cope with crises and shocks, but also reflect on sources and levels of vulnerabilities and thereby understand what anticipatory and coping capacities they need to assess, nurture, and develop in order to anticipate, absorb and react to shocks affecting their finances over time. While a combination of anticipatory and transformative capacities may be required in the face of shocks with significant magnitude, and thus often capacities can be seen as complementary and possibly reinforcing each other, in some cases, a favourable environment and/or the over-reliance on buffering capacities appeared to crowd-out the development of other capacities.

As any analysis, also this study has limitations, in that it focuses on three countries, twelve cases, and the local government level. Also it is based on interviews, which allowed to capture the perceptions of interviewees at the time when the analysis was conducted. Further studies, including cross-country and cross-government analyses, might test the proposed framework and findings using quantitative approaches in order to capture the environmental and 
organizational dimensions, their interplay with (financial) vulnerability, and resulting patterns of governmental financial resilience, or adopt a longitudinal stance by looking at the evolutions of patterns of resilience and related dimensions over several years. Aspects that may deserve further consideration are the external and internal determinants of endogenization and exogenization of vulnerability ${ }^{3}$, as well as the challenges that decision makers face in deploying, while at the same time not exhausting, coping capacities.

\footnotetext{
${ }^{3}$ We owe this idea for further research to one of the reviewers.
} 


\section{References}

Altintas, G. and I. Royer. 2009. 'Renforcement de la résilience par un apprentissage post-crise: une étude longitudinale sur deux périodes de turbulence', $M @ n @ g e m e n t$ 12,4, pp. 26693.

Bhamra, R., S. Dani and K. Burnard. 2011. 'Resilience: the concept, a literature review and future directions', International Journal of Production Research, 49, 18,pp. 5375-93.

Bailey, K.. 2007. Methods of Social Research. 4th edn. New York: Free Press.

Bettis, R.A. and M.A. Hitt. 1995. 'The new competitive landscape', Strategic Management Journal, 16, S1, pp. 7-19.

Boin, A. and A. McConnel. 2007. 'Preparing for Critical Infrastructure Breakdowns: The Limits of Crisis Management and the Need for Resilience', Journal of Contingencies and Crisis Management 15, 1, pp. 50-9.

Boin, A. and M.J.G. Van Eeten. 2013. 'The Resilient Organization', Public Management Review, 15, 3, pp. 429-45.

Boin, A. and M. Lodge. 2016. 'Designing resilient institutions for transboundary crisis management: A time for public administration', Public Administration, 94, 2, pp. $289-98$.

Bozeman, B. 2010. 'Hard Lessons from Hard Times: Reconsidering and Reorienting the “Management Decline" Literature', Public Administration Review, 70, 4, pp. 557-63.

Boyne, G.A. 2006. 'Strategies for Public Service Turnaround. Lessons From the Private Sector?' Administration \& Society, 38, 3,pp. 365-88.

Boyne, G.A. and K.J. Meier. 2009a. 'Environmental Change, Human Resources and Organizational Turnaround', Journal of Management Studies, 46, 5, pp. 835-63.

Boyne, G.A. and K.J. Meier. 2009b. 'Environmental Turbulence, Organizational Stability, and Public Service Performance’, Administration and Society, 40, 8, pp. 799-824.

Bretschneider, S. and W. Gorr. 1992. 'Economic, Organizational, and Political Influences on Biases in Forecasting State Sales Tax Receipts', International Journal of Forecasting, 7, 4, pp. 457-66.

Cepiku, D., R. Mussari and F. Giordano. 2015. 'Local governments managing austerity: approaches, determinants and impact', Public Administration, 94, 1, pp. 223-43.

Coutu, D.L. 2002. 'How Resilience Works', Harvard Business Review, 46-55, https://www.boyden.pt/mediafiles/attachments/7030.pdf.

Darnhofer, I. 2014. 'Resilience and why it matters for farm Management', European Review of Agricultural Economics, 41, 3, pp. 461-84.

Davoudi, S. 2012. 'Resilience: A Bridging Concept or a Dead End?' Planning Theory and Practice, 13, 2, pp. 299-333.

Davoudi, S., E. Brooks, and A. Mehmood. 2013. 'Evolutionary resilience and strategies for climate adaptation', Planning, Practice and Research, 28, pp. 307-22.

Denis, J.-L., L. Lamothe and A. Langley. 2001. 'The Dynamics of Collective Leadership and Strategic Change in Pluralistic Organizations', Academy of Management Journal, 44, 4, pp. 809-37. 
Duit, A. 2016. 'Resilience thinking: Lessons for public administration', Public Administration, 94, 2, pp. 364-80.

Edmondson, A.C., R.M. Bohmer and G.P. Pisano. 2001. 'Disrupted Routines: Team Learning and New Technology Implementation in Hospitals', Administrative Science Quarterly, 46, 4, pp. 685-716.

Eisenhardt, K.M. 1989. 'Building Theories from Case Study Research', The Academy of Management Review, 14, 4, pp. 532-50.

Eisenhardt, K.M. and M.E. Graebner. 2007. 'Theory building from cases: Opportunities and challenges', Academy of Management Journal, 50, 1, pp. 25-32.

Folke, C., S.R. Carpenter, B. Walker, M. Scheffer, T. Chapin and J. Rockström. 2010. 'Resilience Thinking: Integrating Resilience, Adaptability and Transformability', Ecology and Society, 15, 4, 20 [online] URL: http://www.ecologyandsociety.org/vol15/iss4/art20/

Glaser, B. and A. Strauss. 1967. The Discovery of Grounded Theory. Chicago: Aldine.

Gunderson, L.H. and C.S. Holling (eds). 2002. Panarchy: understanding transformations in human and natural systems. Washington, D.C.: Island Press.

Hamel, G.V. and L. Välikangas. 2003. 'The quest for resilience', Harvard Business Review, 81, 9, pp. 52-63.

Hendrick, R.M. 2011. Managing the Fiscal Metropolis. The Financial Policies, Practices, and Health of Suburban Municipalities. Washington, DC: Georgetown University Press.

Hesse, J.J. and L.J. Sharpe. 1991. 'Local government in international perspective. Some comparative observations', in Hesse, J.J. (ed.), Local government and urban affairs in international perspective, Baden-Baden: Nomos.

Holling, C.S. 1973. 'Resilience and Stability of Ecological Systems', Annual Review of Ecology and Systematics, 4, pp. 1-23.

Holling, C.S. 1986. 'Resilience of ecosystems; local surprise and global change', in W.C. Clark and R.E. Munn (eds), Sustainable Development of the Biosphere, Cambridge: Cambridge University Press.

Hood, C. 1991. 'A Public Management for All Seasons?' Public Administration, 69, pp. 3-19.

Hood, C. and M. Wright. 1981. 'From Decrementalism to Quantum Cuts?', in C. Hood and M. Wright, Big Government in Hard Times, Oxford: Wiley-Blackwell.

Huy, Q.N. and H. Mintzberg. 2003. 'The rhythm of change', MIT Sloan Management Review, 44, 4, pp. 79-84.

Jimenez, B.S. 2012. 'Strategic Planning and the Fiscal Performance of City Governments during the Great Recession', The American Review of Public Administration, 43, 5, pp. 581-601.

Jimenez, B.S. 2014. 'Raise Taxes, Cut Services, or Lay Off Staff: Citizens in the Fiscal Retrenchment Process', Journal of Public Administration Research and Theory, 24, 4, pp. 923-53.

Kickert, W. 2012a. 'State Responses to the Fiscal Crisis in Britain, Germany and the Netherlands', Public Management Review, 14, 3, pp. 299-309. 
Kickert, W. 2012b. 'State Responses to the Fiscal Crisis: Belgium', Public Money and Management, 32, 4, pp. 303-10.

Kickert, W. 2013. 'How the Danish Government Responded to the Financial Crisis', Public Money and Management, 33, 1, pp. 55-62.

Kuhlmann, S. 2010. 'Performance Measurement in European local governments: a comparative analysis of reform experiences in Great Britain, France, Sweden and Germany', International Review of Administrative Sciences, 76, 2, pp. 331-45.

Levine, C.H. 1978. 'Organizational Decline and Cutback Management', Public Administration Review, 38, 4,pp. 316-25.

Levine, C.H. 1979. 'More on Cutback Management: Hard Questions for Hard Times', Public Administration Review, 39, 2, pp. 179-83.

Levine, C.H. and P.L. Posner. 1981. 'Centralizing Effects of Austerity on the Intergovernmental System', Political Science Quarterly, 96, 1, pp. 67-85.

Linnenluecke, M.K. 2015. 'Resilience in Business and Management Research: A Review of Influential Publications and a Research Agenda', International Journal of Management Reviews, July 2015, Online First, Early View.

Lodge, M. and C. Hood. 2012. 'Into an Age of Multiple Austerities? Public Management and Public Service Bargains across OECD Countries', Governance: An International Journal of Policy, Administration, and Institutions, 25, 1, pp. 79-101.

Lu, X. and L. Xue. 2016. 'Managing the unexpected: Sense-making in the Chinese emergency management system', Public Administration, 94, 2, pp. 414-29.

Maher, C.S., and S.C. Deller. 2007. 'Municipal Responses to Fiscal Stress', International Journal of Public Administration, 30, 12-14, pp. 1549-72.

Maher, C.S. and S.C. Deller. 2011. 'Measuring municipal fiscal condition: do objective measures of fiscal health relate to subjective measures', Journal of Public Budgeting, Accounting and Financial Management, 23, 3, pp. 455-78.

Mamouni-Limnios, E.A., T. Mazzarol, A. Ghadouani and S.G.M. Schilizzi. 2014. 'The Resilience Architecture Framework: Four organizational archetypes', European Management Journal, 32, pp. 104-16.

Martin, R. and P. Sunley. 2006. 'Path dependence and regional economic evolution', Journal of Economic Geography, 6, pp. 395-437.

McManus, S., E. Seville, D. Brunsdon and J. Vargo. 2007. Resilience Management. A Framework for Assessing and Improving the Resilience of Organizations. http://cpor.org/ro/ResilienceMgmtResearch(2007).pdf

Meier, K.J. and L.J. O'Toole Jr. 2009. 'The Dog that Didn't Bark: How Public Managers Handle Environmental Shocks', Public Administration, 87, 3, pp. 485-502.

Meier, K.J., L.J. O'Toole Jr. and A. Hicklin. 2010. 'I've Seen Fire and I've Seen Rain: Public Management and Performance after a Natural Disaster', Administration and Society, 20, 10, pp. 1-25.

Meyer, A.D. 1982. 'Adapting to Environmental Jolts', Administrative Science Quarterly, 27, 4, pp. 515-37. 
Meyer, R.E. and G. Hammerschmid. 2010. 'The Degree of Decentralization and Individual Decision Making in Central Government Human Resource Management: A European Comparative Perspective', Public Administration, 88, 2, pp. 455-78.

Nelson, D.R., W.N. Adger and K. Brown. 2007. 'Adaptation to Environmental Change: Contributions of a Resilience Framework', Annual Review of Environment and Resources, 32, pp. 395-419.

Neumann, W.L. 2006. Social research methods: qualitative and quantitative approaches. 6th edition. Harlow: Pearson.

O’Toole, L.J. and K.J. Meier. 2010. 'In Defense of Bureaucracy. Public managerial capacity, slack and the dampening of environmental shocks', Public Management Review, 12, 3, pp. 341-61.

Overmans, Tom, and Mirko Noordegraaf. 2014. Managing austerity: rhetorical and real responses to fiscal stress in local government. Public Money and Management 34 (2):99106.

Overmans, T. and K.-P. Timm-Arnold. 2016. 'Managing Austerity: Comparing municipal austerity plans in the Netherlands and North Rhine Westphalia', Public Management Review, 18, 7, pp. 1043-062.

Pandey, Sanjay K. 2010. Cutback Management and the Paradox of Publicness. Public Administration Review 70 (3):564-71.

Patton, M.Q. 2015. Qualitative Research \& Evaluation Methods. Integrating Theory and Practice. $4^{\text {th }}$ edition. London: Sage.

Peters, B.G. 2011. 'Governance Responses to the Fiscal Crisis - Comparative Perspectives', Public Money and Management, 31, 1, pp. 75-80.

Peters, B.G., J. Pierre and T. Randma-Liiv. 2011. 'Global Financial Crisis, Public Administration and Governance: Do New Problems Require New Solutions?' Public Organization Review, 11, pp. 13-27.

Pettigrew, A.M. 1990. 'Longitudinal Field Research on Change: Theory and Practice', Organization Science, 1, 3, pp. 267-92.

Pike, A., S. Dawley and J. Tomaney. 2010. 'Resilience, Adaptation and Adaptability', Cambridge Journal of Regions, Economy and Society, 3, pp. 59-70.

Pollitt, C. 2010. 'Cuts and Reforms - Public Services As We Move Into A New Era', Society and Economy, 32, 1, pp. 17-31.

Pollitt, C. and G. Bouckaert. 2011. 'Public Management Reform: A Comparative Analysis New Public Management, Governance, and the Neo-Weberian State', International Review of Administrative Sciences, 78, 1, pp.180-82.

Posner, P. and J. Blöndal. 2012. 'Democracies and Deficits: Prospects for Fiscal Responsibility in Democratic Nations', Governance, 25, 1, pp. 11-34.

Pickett, S.T.A., M.L. Cadenasso and J.M. Grove. 2004. 'Resilient Cities: Meaning, Models, and Metaphor for Integrating the Ecological, Socio-Economic, and Planning Realms', Landscape and Urban Planning, 69, 4, pp. 369-84.

Przeworski, A. and H. Teune. 1970. The logic of comparative social inquiry. New York City: Wiley and Sons. 
Raudla, R., R. Savi and T. Randma-Liiv. 2013. 'Literature review on cutback management, COCOPS deliverable 7.1.' Accessed 12 December 2014, http://www.cocops.eu/wpcontent/uploads/2013/03/COCOPS_Deliverable_7_1.pdf.

Ridder, H.-G., H.-J. Bruns and F. Spier. 2006. 'Managing implementation processes', Public Management Review, 8, 1, pp. 87-118.

Rose, S. and D.L. Smith. 2011. 'Budget Slack, Institutions, and Transparency', Public Administration Review, 22, 2, pp. 187-95.

Schick, A. 1980. Congress and Money. Budgeting, Spending, and Taxing. Washington, D.C.: Urban Institute.

Scorsone, E.A. and C. Plerhoples. 2010. 'Fiscal Stress and Cutback Management Amongst State and Local Governments: What Have We Learned and What Remains to be Learned?' State and Local Government Review, 42, 2, pp. 176-87.

Shaw, K. 2012. 'The Rise of the Resilient Local Authority?' Local Government Studies, 38, 3, pp. 281-300.

Somers, S. 2009. 'Measuring Resilience Potential: An Adaptive Strategy for Organizational Crisis Planning', Journal of Contingencies and Crisis Management, 17, 1, pp. 12-23.

Stewart, J. 2012. 'Multiple-case Study Methods in Governance-related Research', Public Management Review, 14, 1, pp. 67-82.

Suddaby, R. 2006. 'What grounded theory is not', Academy of Management Journal, 49, 4, pp. 633-42.

Sutcliffe, K.M. and T.J. Vogus. 2003. 'Organizing for resilience', in K.S. Cameron, J.E. Dutton and R.E. Quinn (eds), Positive Organizational Scholarship: Foundations of a New Discipline. San Francisco, CA.: Berrett-Koehler.

Trochim, W. and J. Donnelly. 2006. The Research Knowledge Methods Base. Hampshire: Cengage Learning.

Vickers, M.H. and A. Kouzmin. 2001. "'Resilience" in organizational actors and rearticulating "voice": towards a humanistic critique of new public management', Public Management Review, 3, 1, pp. 95-119.

Van der Vegt, G., P. Essens, M. Wahlstrom and G. George. 2015. 'Managing Risk and Resilience', Academy of Management Journal, 58, 4, pp, 971-80.

Weick, K.E. and Sutcliffe, K.M. 2007. Managing the unexpected: Resilient performance in an age of uncertainty. San Francisco, CA: Jossey-Bass.

West, J.P., and S.E. Condrey. 2011. 'Municipal Government Strategies for Controlling Personnel Costs During the Fiscal Storm', Journal of Public Budgeting, Accounting and Financial Management, 23, 3, pp. 395-426.

Wildavsky, A.B. 1988. The New Politics of the Budgetary Process. Glenwiew, IL: Scott, Foresman.

Wolman, H. 2008. 'Comparing local government systems across countries: conceptual and methodological challenges to building a field of comparative local government studies', Environment and Planning C: Government and Policy, 26, pp. 87-103.

Yin, R.K. 2009. Case Study Research: Design and Methods. 4th ed. Thousand Oaks: Sage. 
Figure 1 - Financial Resilience Framework

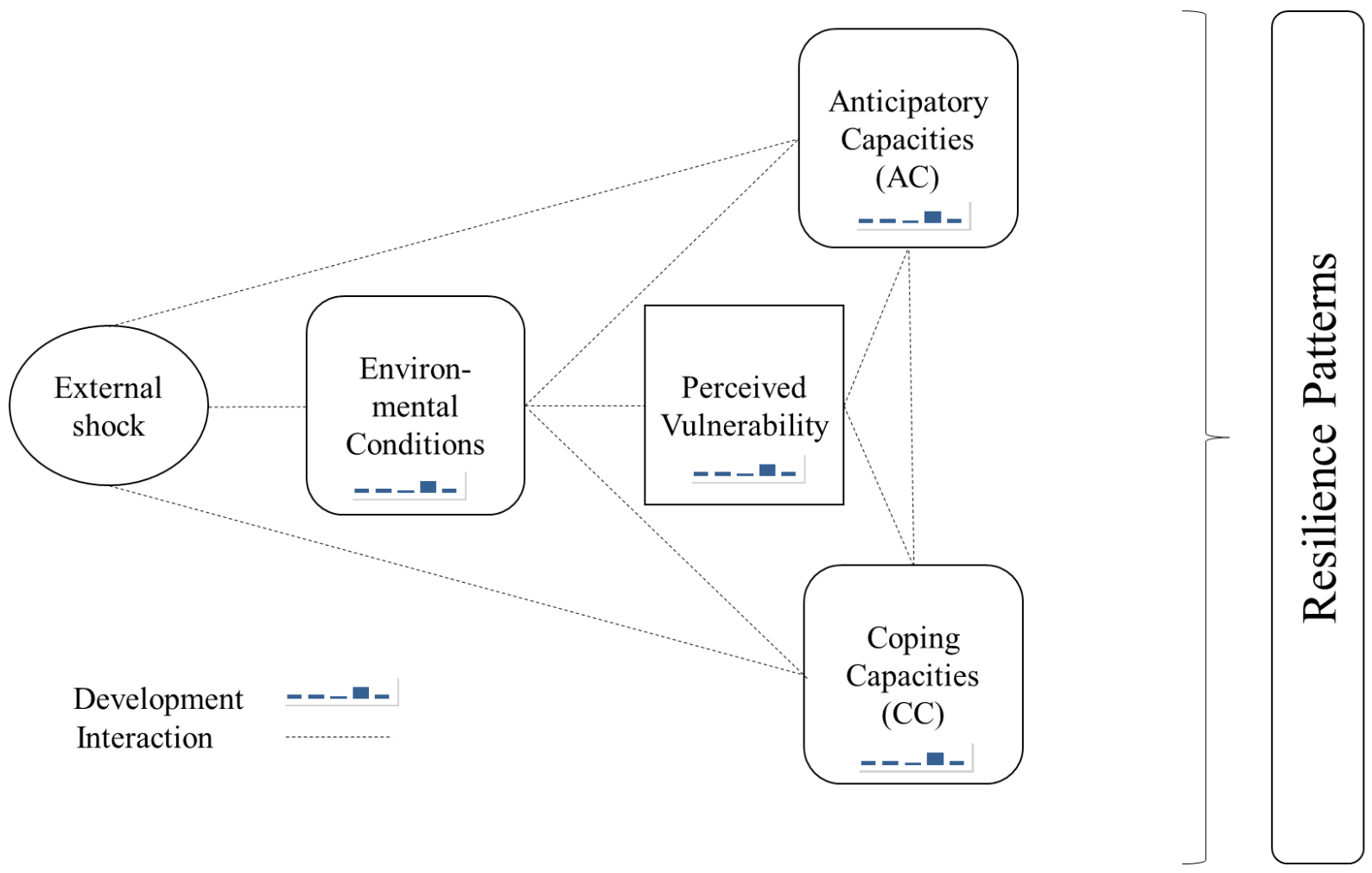


Appendix Table 1 - Country comparison, general indicators

\begin{tabular}{|c|c|c|c|}
\hline & Austria & Italy & UK-England \\
\hline Population in mio. & 8.47 & 59.69 & 63.91 \\
\hline GDP per capita in Euro & 37,000 & 25,600 & 29,600 \\
\hline General debt level as $\%$ of GDP & $89 \%$ & $145 \%$ & $105 \%$ \\
\hline $\begin{array}{l}\text { General fiscal balance as \% of } \\
\text { GDP }\end{array}$ & $-1 \%$ & $-3 \%$ & $-6 \%$ \\
\hline Administrative tradition & Continental European model & Southern European Model & Anglo-Saxon Model \\
\hline No. of LGs & 2,357 & 8,092 & 9,000 \\
\hline $\begin{array}{l}\text { No. of seats of district } \\
\text { authorities/seats of } \\
\text { province/STCCs }\end{array}$ & 72 & 117 & 152 \\
\hline Level of decentralization & Federal & Unitary ("Quasi-federal") & Unitary \\
\hline LG profiles & North Middle European Group & Franco Group & Anglo-Group \\
\hline Main LG fiscal sources & $\begin{array}{l}\text { Municipal business tax (payroll } \\
\text { tax); resident property tax; fees } \\
\text { and charges }\end{array}$ & $\begin{array}{c}\text { Municipal property tax; } \\
\text { household waste tax; } \\
\text { tax on the occupation of public } \\
\text { spaces and areas; local } \\
\text { advertising tax; surtax on } \\
\text { personal income tax; fees and } \\
\text { charges; surtax on electricity } \\
\text { consumption; municipal tax on } \\
\text { building licences } \\
\text { provincial vehicle insurance tax } \\
\text { and registration tax; regional tax } \\
\text { on productive output; regional } \\
\text { automobile tax; fuel duty }\end{array}$ & $\begin{array}{l}\text { Council tax (resident property); } \\
\text { retained and redistributed non- } \\
\text { domestic rates (business rates); } \\
\text { other government grants } \\
\text { (including specific government } \\
\text { grants); sales, fees and charges; } \\
\text { council rents }\end{array}$ \\
\hline Main LG shared taxes & $\begin{array}{l}\text { Value added tax; property } \\
\text { acquisition tax; corporate } \\
\text { income tax; personal income } \\
\text { tax; petrol tax }\end{array}$ & $\begin{array}{c}\text { Personal income tax } \\
\text { (municipalities and provinces); } \\
\text { personal income tax and } \\
\text { corporate income tax (regions } \\
\text { with special status) }\end{array}$ & $\begin{array}{c}\text { Business rates (business } \\
\text { property tax) }\end{array}$ \\
\hline Financial arrangements & $\begin{array}{l}\text { Centralized collection with re- } \\
\text { distribution agreement of main } \\
\text { taxes (VAT, income taxes) and } \\
\text { state caps on LG taxes } \\
\text { Deficit/surplus targets for } \\
\text { central and sub-central } \\
\text { government and sanctioning } \\
\text { mechanism set in Stability Pact } \\
\text { Issuance of LG own debt } \\
\text { allowed only to finance capital } \\
\text { expenditure, approval required } \\
\text { depending on state government } \\
\text { regulation, cap on debt } \\
\text { depending on the state } \\
\text { government }\end{array}$ & $\begin{array}{l}\text { Annual constraints on } \\
\text { expenditure and/or the budget } \\
\text { balance of sub-central } \\
\text { government set in } \\
\text { Stability Pact } \\
\text { Issuance of LG own debt } \\
\text { allowed only to finance capital } \\
\text { expenditure, no approval by } \\
\text { upper-level government } \\
\text { required, cap on debt service }\end{array}$ & $\begin{array}{l}\text { Central grant distribution } \\
\text { determined by centrally set } \\
\text { funding formula, including } \\
\text { redistribution of business rates } \\
\text { (amended } 2014 / 15 \text { to include an } \\
\text { element of business rates } \\
\text { retained locally } \\
\text { Statutorily required to set a } \\
\text { balanced budget } \\
\text { Issuance of LG own debt } \\
\text { allowed only to finance capital } \\
\text { expenditure, no approval by } \\
\text { upper-level government } \\
\text { required, internally set caps on } \\
\text { debt }\end{array}$ \\
\hline
\end{tabular}

All figures 2013. Data taken from OECD databases and national statistics offices. Information on financial arrangements: European Commission (2012). 
Appendix Table 2: Financial data across cases

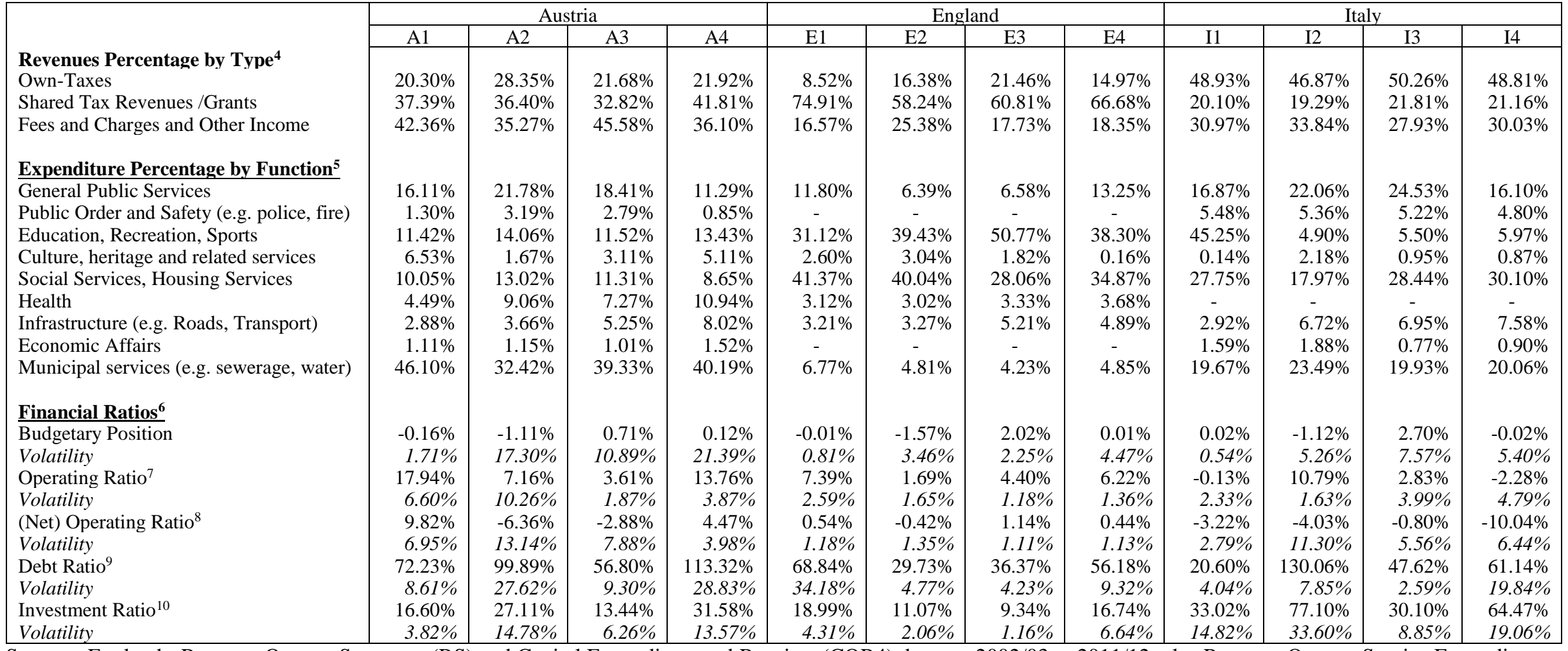

Sources: England - Revenue Outturn Summary (RS) and Capital Expenditure and Receipts (COR4) datasets 2002/03 to 2011/12, plus Revenue Outturn Service Expenditure

Summary (RSX) datasets 2006/06 to 2011/12 - Department for Communities and Local Government (DCLG), United Kingdom

${ }^{4}$ Ten year average between 2002 and 2011 for Austria and Italy, 7 year average between 2005/06 and 20011/12 for England due to availability of data

${ }^{5}$ Based on 2013 actuals for Austria and Italy and 2013/14 actuals for England

${ }^{6}$ Ten year averages between 2002 and 2011 for Austria and Italy and 2002/03 and 2011/12 for England

7 (Total operating revenues - Total operating expenditures)/Total operating revenues

${ }^{8}$ (Total operating revenues - Total operating expenditure - Debt repayment) / Total operating revenues [debt repayment = Interest paid; in the UK also includes Minimum

Revenue Provision]

${ }^{9}$ (Outstanding debt/Total Operating revenues)

${ }^{10}$ (Capital Expenditure on assets, grants/loans awarded and equity acquisition)/Operating Income 


\section{Appendix Table 3: Variable definition and operationalization}

Note: text in [brackets] indicates the themes emerging from interviews

\begin{tabular}{|c|c|c|}
\hline $\begin{array}{l}\text { Variable and } \\
\text { definition }\end{array}$ & $\begin{array}{l}\text { Categories and } \\
\text { definition }\end{array}$ & Quotes (Examples) \\
\hline $\begin{array}{l}\text { Financial } \\
\text { shock } \\
\text { Major } \\
\text { unexpected } \\
\text { event in the } \\
\text { external } \\
\text { environment } \\
\text { perceived as } \\
\text { affecting LG } \\
\text { finances }\end{array}$ & $\begin{array}{l}\text { Financial } \\
\text { crisis and } \\
\text { consequences } \\
\text { The } \\
\text { phenomenon } \\
\text { of a series of } \\
\text { crises } \\
\text { experienced in } \\
2007-2009 \text { and } \\
\text { their aftermath, } \\
\text { in literature } \\
\text { broadly } \\
\text { referred to as } \\
\text { the 'Global } \\
\text { Financial } \\
\text { Crisis' or 'the } \\
\text { Great } \\
\text { Recession' }\end{array}$ & $\begin{array}{l}\text { "2009/2010 was then the economic crisis [economic crisis], that has posed a problem." } \\
\text { (CFO, A2) } \\
\text { "The big change was certainly the financial crisis in } 2008 \text { [financial crisis]." (CFO, A4) } \\
\text { "The economic crisis [economic crisis] affects building policies (urban plans do not start)." } \\
\text { (CEO, I2) } \\
\text { "Today we have lower revenues from building permits... this is the consequence of the } \\
\text { economic crisis." (Staff, Office for the budget, I4) } \\
\text { "The largest one has been the financial crisis [financial crisis] and there were other ones } \\
\text { that were a consequence [austerity] of that." (Service Director, E2) } \\
\text { "I think it [the financial crisis] was a shock, it was very shocking." (CEO, E3) } \\
\text { "We had planned for further reductions but it turned out to be a lot lot worse than....our } \\
\text { savings target overnight went up [austerity] from } £ 127 \text { to } £ 157 \text { million over a } 5 \text { year period } \\
\text { and that I would say was a shock." (CFO, E3) }\end{array}$ \\
\hline $\begin{array}{l}\text { External } \\
\text { environment } \\
\text { The } \\
\text { institutional, } \\
\text { economic and } \\
\text { social } \\
\text { environment in } \\
\text { which local } \\
\text { governments } \\
\text { operate }\end{array}$ & $\begin{array}{l}\text { Institutional } \\
\text { environment } \\
\text { The system of } \\
\text { rules, } \\
\text { regulations, } \\
\text { policies set by } \\
\text { upper } \\
\text { governmental } \\
\text { levels and } \\
\text { under which } \\
\text { local } \\
\text { governments } \\
\text { operate }\end{array}$ & $\begin{array}{l}\text { "We have no control over the bigger part of revenues and expenditures [fiscal } \\
\text { regulations/autonomy]." (CFO, A3). } \\
\text { "Every year the law changes [fiscal regulations/uncertainty] - the Stability Pact, transfers." } \\
\text { (CFO, I4) } \\
\text { "We have the most centralized system of resource allocation [fiscal regulations/autonomy] } \\
\text { to be found anywhere in Europe, so therefore our dependency on the priorities of central } \\
\text { government...is therefore clearer and more visible than it is elsewhere." (CEO E1) } \\
\text { "Most people will see the headlines that local authorities are allowed to keep } 50 \% \text { of business } \\
\text { rates. We get to keep } 27 \% \text { [fiscal regulations/autonomy] in E2 because we are deemed to be } \\
\text { too affluent to start with..." (CFO, E2) } \\
\text { "We plan in a medium-term perspective, we have to - by law [planning rules]. (CFO, A4) } \\
\text { "[It] says in a LAAP bulletin (as part of the regulatory environment) you must risk assess } \\
\text { [monitoring rules], so every year we risk assess and we include it in our } 5 \text { year financial } \\
\text { plan." (CFO, E3) }\end{array}$ \\
\hline & $\begin{array}{l}\text { Economic } \\
\text { environment } \\
\text { Economic } \\
\text { conditions of } \\
\text { the area where } \\
\text { the local } \\
\text { government } \\
\text { operates }\end{array}$ & $\begin{array}{l}\text { "Luckily we have financially strong businesses that pay a lot of municipal taxes [strong } \\
\text { economic base]." (CEO, A4) } \\
\text { "We have many small and medium sized enterprises [diversified economic base]" (CEO, } \\
\text { A3) } \\
\text { "We are a very successful city generating lots of jobs, lots of growth in economic terms } \\
\text { [economic growth]" (CFO, E1) } \\
\text { "In E3 we were not always positioned well in terms of opportunities for finances [weak } \\
\text { financing opportunities].... We have got some very affluent areas and some very deprived } \\
\text { areas..." (CEO, E3) } \\
\text { "[E4] is not the most affluent of areas, so in terms of council tax, we don't have lot in terms } \\
\text { of council tax yield [weak financing opportunities]..... We don't have an industry that is } \\
\text { specific to [E4]..." (CEO \& CFO, E4) }\end{array}$ \\
\hline & 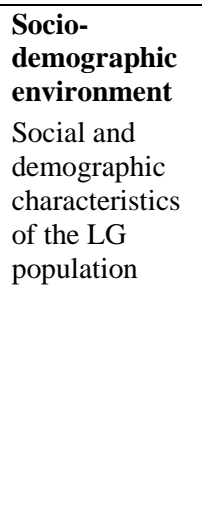 & $\begin{array}{l}\text { "We are rather declining [decreasing population] that hurts us since grants are related to the } \\
\text { population." (CEO, A3) } \\
\text { "There has been a gradual deterioration of the ability of citizens to pay. (...) And also in } \\
\text { relation to the demand for services (canteens, nurseries) the percentage of unrealized } \\
\text { revenues is increasing. [increasing deprived population]" (CFO, I4) } \\
\text { "You know, the population has increased by over 100,000. We have the fastest growth } \\
\text { [population growth] in the country. That has brought great challenges. We used to be } \\
\text { known to have an ageing population [ageing population], now there is an absolute } \\
\text { explosion of young people [influx of younger people] coming to live in the city." (CEO, } \\
\text { E1) } \\
\text { "We've got more people with disabilities [high level of disabilities] living longer, we've } \\
\text { got an ageing population and demographic changes [ageing population], E4 is going as fast } \\
\text { as anywhere in the UK. We've got no taxes to pay for these services..." (Service Director, } \\
\text { E4) }\end{array}$ \\
\hline $\begin{array}{l}\text { Perceived } \\
\text { Vulnerability }\end{array}$ & & $\begin{array}{l}\text { "We have many small and medium sized enterprises, and therefore we did not have such an } \\
\text { impact on the municipal tax [strong and diversified tax revenues] the crisis hit us, we had to } \\
\text { increase the debt level [high debt financing] to finance our investments." (CFO, A3)...the }\end{array}$ \\
\hline
\end{tabular}




\begin{tabular}{|c|c|c|}
\hline $\begin{array}{l}\text { Perceived } \\
\text { exposure to } \\
\text { financial } \\
\text { shocks and } \\
\text { disturbances }\end{array}$ & & 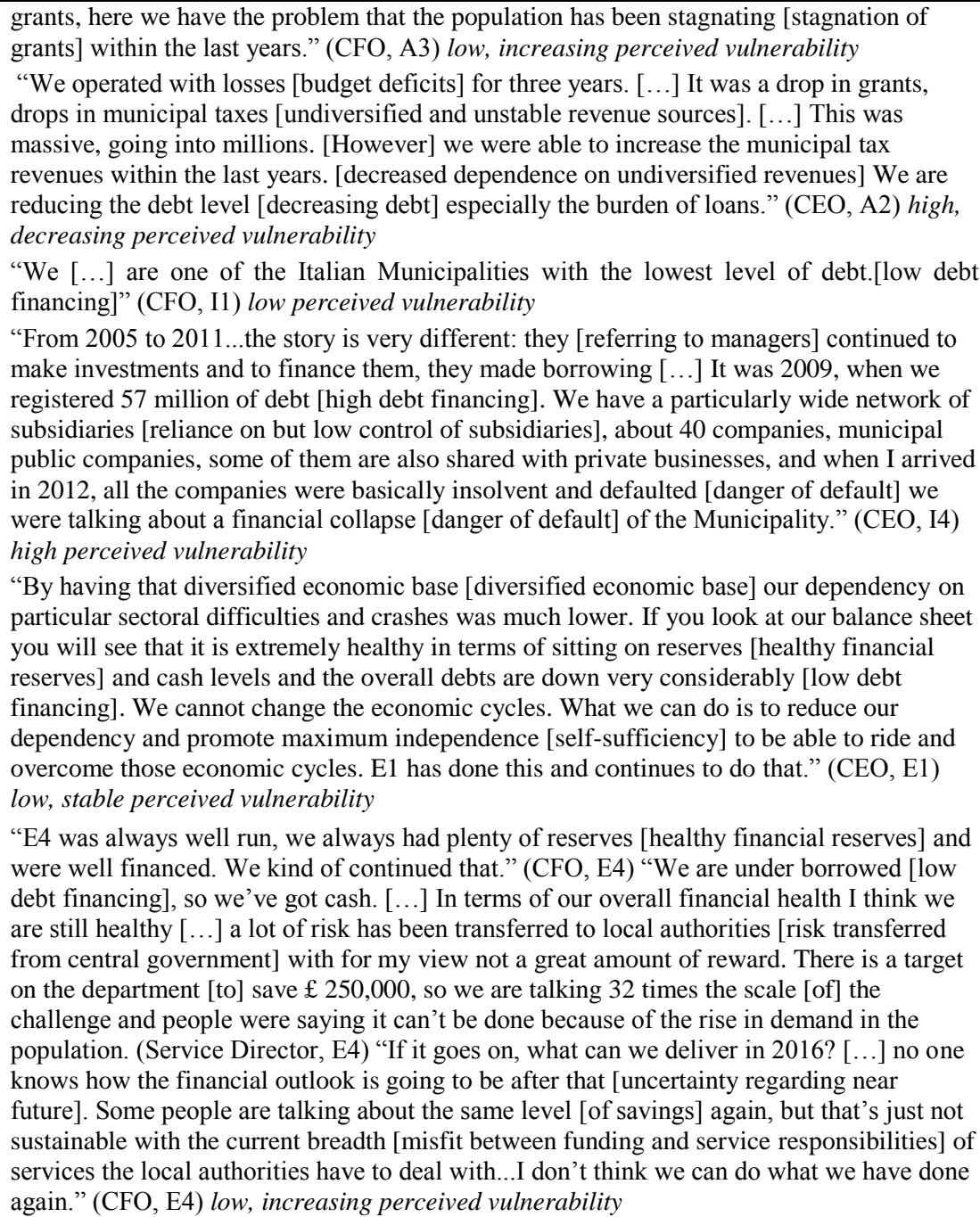 \\
\hline $\begin{array}{l}\text { Anticipatory } \\
\text { Capacities } \\
\text { The ability to } \\
\text { identify and } \\
\text { manage LG } \\
\text { vulnerabilities, } \\
\text { to recognize } \\
\text { (potential) } \\
\text { shocks in an } \\
\text { early stage, } \\
\text { and to } \\
\text { understand } \\
\text { their impact on } \\
\text { the LG }\end{array}$ & $\begin{array}{l}\text { Tools that are } \\
\text { used to } \\
\text { monitor the } \\
\text { environment } \\
\text { and help to } \\
\text { identify and } \\
\text { manage LG } \\
\text { vulnerabilities. } \\
\text { The tools can } \\
\text { exist or be } \\
\text { built up } \\
\text { internally- } \\
\text { driven, or } \\
\text { externally- } \\
\text { driven, e.g. } \\
\text { instruments } \\
\text { required by } \\
\text { upper } \\
\text { governmental } \\
\text { levels LG } \\
\text { actors' mental } \\
\text { processes of } \\
\text { knowing, } \\
\text { including } \\
\text { awareness, } \\
\text { perception, } \\
\text { reasoning and } \\
\text { judgment. The } \\
\text { cognitive } \\
\text { anticipatory }\end{array}$ & $\begin{array}{l}\text { "We still managed to master this [crisis] well [...] this is also due to a conscious financial } \\
\text { management. It is the administration's responsibility to warn in time. [...] I mean, the } \\
\text { signals were there... [cautious planning, monitoring and control processes]" (CEO, A1) } \\
\text { high anticipatory capacity } \\
\text { "The economic crisis [...] it caught us unprepared because we did not recognize its } \\
\text { dimension. [low environmental (trends) and self-awareness]" (CFO, A2) low anticipatory } \\
\text { capacity } \\
\text { "Well, I have to say that political actors now are aware [increasing awareness] that you } \\
\text { have to maintain the balance, one can observe this. [weak medium-term financial } \\
\text { planning][...] The quarterly reports are a monitoring tool [enhanced financial monitoring]" } \\
\text { (CFO, A3) increasing anticipatory capacity } \\
\text { "Let's say that they [managers] know [the financial constraints], but they often simply } \\
\text { ignore it. [weak awareness]" (CFO, I3) low anticipatory capacity } \\
\text { "The antidote to such a changing, uncertain and unpredictable situation is to use prudence } \\
\text { and gradualness in the assumption of expenditure obligations. [strong planning]" (CFO, I1) } \\
\text { "We try to make good predictions, [...] through careful monitoring [monitoring and control } \\
\text { processes, simulation]. The budget is not written once but is constantly reviewed during the } \\
\text { year. [monitoring and control processes, re-budgeting]" (CEO, I1) high anticipatory } \\
\text { capacity } \\
\text { "We implemented a new management system, [...] thus we are able to schedule the } \\
\text { activities at the beginning of each year and to monitor the results, even in terms of } \\
\text { management control. [enhanced planning and monitoring]" (CEO, I4) increasing } \\
\text { anticipatory capacity } \\
\text { "No, we didn't invest in Icelandic Banks we saw the writing on the wall months before, } \\
\text { there were enough rumours out there, emails, } 7 \text { to } 6 \text { months before. We have never had any } \\
\text { long-term deposits in Iceland Banks so we have never had any treasury risks like that. Most } \\
\text { people hadn't anticipated but we had. We have also put £10 million aside } 14 / 15 \text { for any } \\
\text { residual on [...] the appeals side. [high environmental awareness]" (CFO, E1) high } \\
\text { anticipatory capacity }\end{array}$ \\
\hline
\end{tabular}




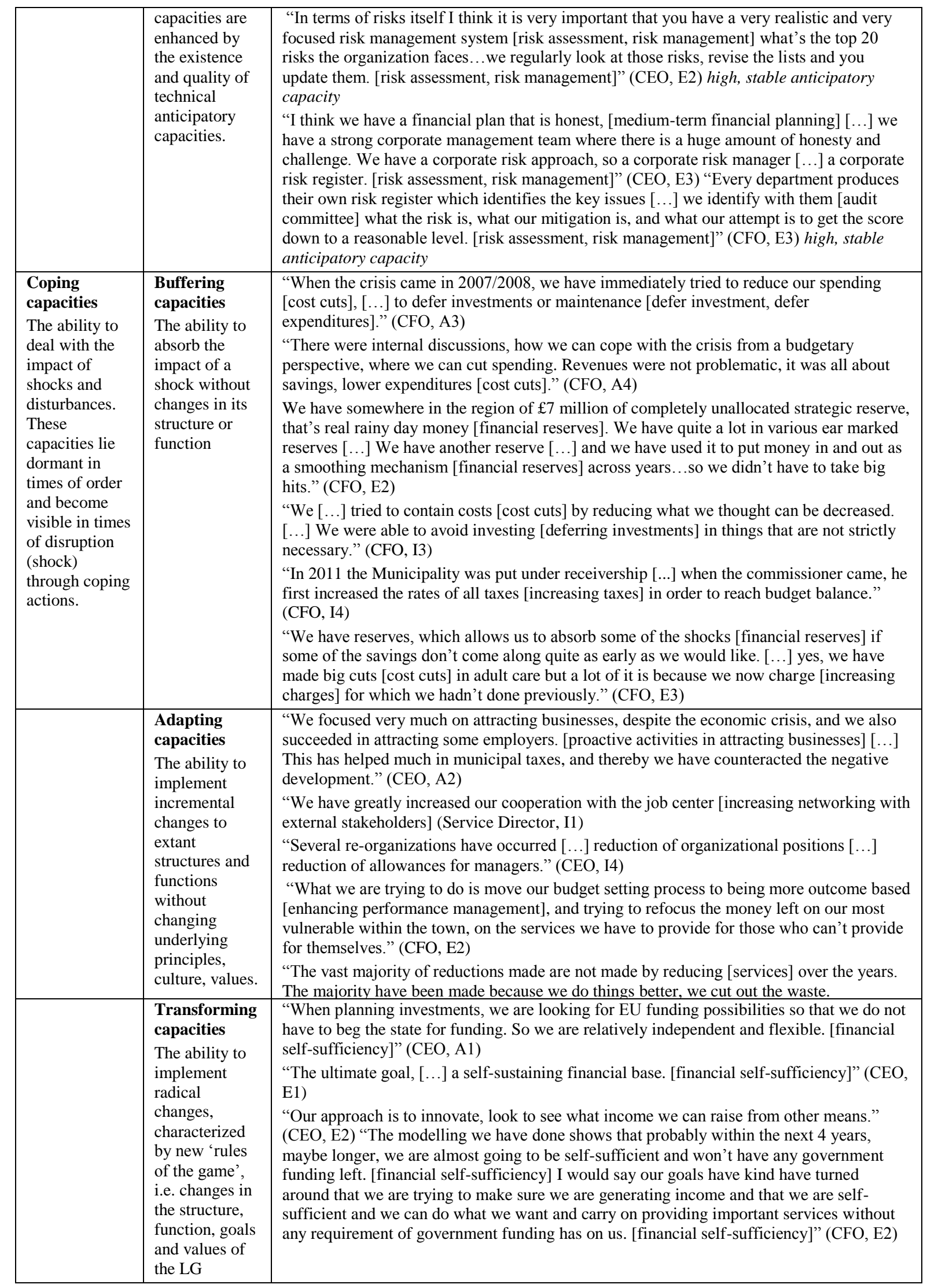


Appendix Table 4: Pattern 1 - Self-regulatory resilience.

\begin{tabular}{|c|c|c|c|c|}
\hline & A1 & E1 & E2 & I1 \\
\hline Budgetary position & Zero & Zero & Negative & Zero \\
\hline Volatility & Low & Low & High & Low \\
\hline Context & $\begin{array}{c}\text { Institutional } \\
\text { Obligatory but non-binding } \\
\text { medium term financial } \\
\text { planning } \\
\text { Economic } \\
\text { Strong and diversified } \\
\text { economic base, poor region } \\
\\
\text { Socio-demographic } \\
\text { Population stagnation, } \\
\text { shrinking region }\end{array}$ & $\begin{array}{c}\text { Institutional } \\
\text { Centralized system of } \\
\text { resource allocation, limits } \\
\text { on local tax increases } \\
\text { (referendum) } \\
\text { Economic } \\
\text { Strong and diversified } \\
\text { economic base, economic } \\
\text { growth } \\
\\
\text { Socio-demographic } \\
\text { Population growth, ageing } \\
\text { population, influx of } \\
\text { younger people, } \\
\text { unemployment }\end{array}$ & $\begin{array}{c}\text { Institutional } \\
\text { Centralized system of } \\
\text { resource allocation, limits } \\
\text { on local tax increases } \\
\text { (referendum) } \\
\text { Economic } \\
\text { New Town status eases } \\
\text { planning and development } \\
\text { processes, wealthy } \\
\text { economic region } \\
\text { Socio-demographic } \\
\text { Population growth }\end{array}$ & $\begin{array}{c}\text { Institutional } \\
\text { Financial dependence of } \\
\text { LGs on central decisions } \\
\text { and grants } \\
\text { Economic } \\
\text { Wealthy economic region, } \\
\text { housing bubble since the } \\
\text { beginning of the Millennium } \\
\text { Socio-demographic } \\
---\end{array}$ \\
\hline Financial shocks & $\begin{array}{l}\text { Financial crisis, grant } \\
\text { reduction }\end{array}$ & $\begin{array}{l}\text { Grant reduction, reduced } \\
\text { business rates income due to } \\
\text { appeals (unfunded) }\end{array}$ & $\begin{array}{c}\text { Financial crisis, grant } \\
\text { reduction to negligible } \\
\text { levels, low business rates } \\
\text { retention due to affluence } \\
\text { and reduced business rates } \\
\text { income due to appeals } \\
\text { (unfunded) }\end{array}$ & $\begin{array}{l}\text { Grant reduction, increased } \\
\text { demand for services, } \\
\text { tightening of fiscal targets, } \\
\text { re-centralization of } \\
\text { decisions and financial } \\
\text { controls, regulatory } \\
\text { uncertainty } \\
\end{array}$ \\
\hline $\begin{array}{l}\text { Perceived } \\
\text { vulnerability levels } \\
\text { and sources before } \\
\text { the shock and their } \\
\text { /evolution over time } \\
*\end{array}$ & $\begin{array}{c}\text { Initially low } \\
\text { stable over time } \\
\text { Low debt financing, healthy } \\
\text { financial reserves, } \\
\text { /alternative income sources }\end{array}$ & $\begin{array}{c}\text { Initially low } \\
\text { stable over time } \\
\text { Low debt financing, } \\
\text { alternative income sources, } \\
\text { healthy financial reserves }\end{array}$ & $\begin{array}{c}\text { Initially medium } \\
\text { decreasing over time } \\
\text { Low financial reserves, } \\
\text { dependency on central } \\
\text { grants } \\
\text { /alternative income sources } \\
\text { (tax), decreasing } \\
\text { dependence on central } \\
\text { grants, increasing financial } \\
\text { reserves }\end{array}$ & $\begin{array}{c}\text { Initially low } \\
\text { stable over time } \\
\text { Low debt financing, high } \\
\text { level of revenue recovery }\end{array}$ \\
\hline $\begin{array}{l}\text { Level and types of } \\
\text { anticipatory capacity } \\
\text { before the shock and } \\
\text { their /evolution over } \\
\text { time ** }\end{array}$ & $\begin{array}{c}\text { Initially high } \\
\text { stable over time } \\
\text { Embedded medium-term } \\
\text { financial planning, cautious } \\
\text { planning, monitoring and } \\
\text { control processes }\end{array}$ & $\begin{array}{c}\text { Initially high } \\
\text { stable over time } \\
\text { Medium-term financial } \\
\text { planning, risk assessment } \\
\text { and other monitoring tools, } \\
\text { environmental and self- } \\
\text { awareness } \\
\end{array}$ & $\begin{array}{c}\text { Initially high } \\
\text { stable over time } \\
\text { Medium-term financial } \\
\text { planning, risk assessment } \\
\text { and other monitoring tools }\end{array}$ & $\begin{array}{c}\text { Initially high } \\
\text { stable over time } \\
\text { Risk assessment, strong } \\
\text { planning, monitoring and } \\
\text { control processes (e.g., } \\
\text { simulations, re-budgeting) }\end{array}$ \\
\hline $\begin{array}{l}\text { Levels ad types of } \\
\text { coping capacity*** }\end{array}$ & $\begin{array}{c}\text { Comprehensive } \\
\text { Buffering: } \\
\text { Financial reserves, cost cuts, } \\
\text { deferring investments } \\
\text { Adapting: } \\
\text { Enhancing internal } \\
\text { competencies, restructuring } \\
\text { and collegiate planning, } \\
\text { partnerships with private } \\
\text { developers } \\
\text { Transforming: } \\
\text { Financial self-sufficiency } \\
\text { (alternative income sources) }\end{array}$ & $\begin{array}{c}\text { Comprehensive } \\
\text { Buffering: } \\
\text { Financial reserves, cost cuts, } \\
\text { increasing fees and charges, } \\
\text { virements, prioritization } \\
\text { Adapting: } \\
\text { Invest to save, efficiencies, } \\
\text { risk management and } \\
\text { performance management, } \\
\text { collegiate planning, task } \\
\text { review, partnerships } \\
\text { Transforming: } \\
\text { Autonomy and financial } \\
\text { self-sufficiency }\end{array}$ & $\begin{array}{c}\text { Comprehensive } \\
\text { Buffering: } \\
\text { Financial reserves, cost cuts, } \\
\text { increasing fees and charges, } \\
\text { virements } \\
\text { Adapting: } \\
\text { Invest to save, enhancing } \\
\text { performance management, } \\
\text { partnerships with private } \\
\text { developers, collegiate } \\
\text { planning } \\
\text { Transforming: } \\
\text { Financial self-sufficiency }\end{array}$ & $\begin{array}{c}\text { Comprehensive } \\
\text { Buffering: } \\
\text { Cost cuts, increasing fees } \\
\text { and charges, prioritization, } \\
\text { deferring investments } \\
\text { Adapting: } \\
\text { Increasing control of } \\
\text { subsidiaries, rationalization, } \\
\text { increasing networking with } \\
\text { external stakeholders } \\
\text { Transforming: } \\
---\end{array}$ \\
\hline
\end{tabular}

* This row contains information on the initial levels/ the changes in vulnerability over time, the initial vulnerability sources before the financial shock / their evolution over time.

** This row contains information on the initial level /the changes in anticipatory capacity over time, the initial types of anticipatory capacities before the financial shock/their evolution over time.

*** Level of coping capacity: limited - the few coping actions and main focus on buffering indicate limited coping capacities; selective - several coping actions of buffering and adapting indicate selective coping capacities; comprehensive - the full use of the spectrum of coping actions in buffering, adapting and transforming, indicate comprehensive coping capacities. 
Appendix Table 5: Pattern 2 and 3- Constrained and reactive adaptation.

\begin{tabular}{|c|c|c|c|c|}
\hline & E3 (ConstrainedAdapters) & E4 (Constrained Adapters) & A2 (Reactive adapters) & I4 (Reactive Adapters) \\
\hline Budgetary position & Positive & Zero & Negative & Zero \\
\hline Volatility & High & High & High & High \\
\hline Context & $\begin{array}{c}\text { Institutional } \\
\text { Centralized system of } \\
\text { resource allocation, limits } \\
\text { on local tax increases } \\
\text { (referendum), dependence of } \\
\text { LGs on central government } \\
\text { transfers and grants } \\
\text { Economic } \\
\text { Weak financing } \\
\text { opportunities due to } \\
\text { geographical position } \\
\\
\text { Socio-demographic } \\
\text { Ageing population, high } \\
\text { level of disabilities and } \\
\text { complex needs }\end{array}$ & $\begin{array}{c}\text { Institutional } \\
\text { Centralized system of } \\
\text { resource allocation, limits } \\
\text { on local tax increases } \\
\text { (referendum), dependence of } \\
\text { LGs on central government } \\
\text { transfers and grants } \\
\text { Economic } \\
\text { Weak financing } \\
\text { opportunities due to the lack } \\
\text { of industries at the local } \\
\text { level } \\
\text { Socio-demographic } \\
\text { Ageing population, high } \\
\text { level of disabilities }\end{array}$ & $\begin{array}{c}\text { Institutional } \\
\text { No control over large share } \\
\text { of revenues (grants) and } \\
\text { expenditures (transfer } \\
\text { payments), low LG } \\
\text { autonomy, strict oversight } \\
\text { regulations (limits on loans) } \\
\text { Economic } \\
\text { Industry-dependent, big } \\
\text { employers }\end{array}$ & $\begin{array}{c}\text { Institutional } \\
\text { Dependence of LGs on } \\
\text { central decisions and grants } \\
\text { Economic } \\
\text { Housing bubble since the } \\
\text { beginning of the Millennium } \\
\text { Socio-demographic } \\
\text { Increasing deprived } \\
\text { population }\end{array}$ \\
\hline Financial shocks & $\begin{array}{l}\text { Financial crisis, grant } \\
\text { reduction, increased demand } \\
\text { for services }\end{array}$ & $\begin{array}{l}\text { Grant reduction, equal status } \\
\text { scheme, risk transferred } \\
\text { from central government } \\
\text { due to new council tax } \\
\text { benefit scheme and business } \\
\text { rates retention appeals (both } \\
\text { unfunded) }\end{array}$ & $\begin{array}{l}\text { Financial crisis, grant } \\
\text { reduction and tax decrease }\end{array}$ & $\begin{array}{l}\text { Grant reduction, decreasing } \\
\text { revenues from building } \\
\text { permits, , tightening of fiscal } \\
\text { targets, re-centralization of } \\
\text { decisions, regulatory } \\
\text { uncertainty }\end{array}$ \\
\hline $\begin{array}{l}\text { Perceived } \\
\text { vulnerability levels } \\
\text { and sources before } \\
\text { the shock and their } \\
\text { /evolution over time } \\
*\end{array}$ & $\begin{array}{c}\text { Initially low } \\
\text { Increasing over time } \\
\text { Healthy financial reserves } \\
\text { /dependence on grants, } \\
\text { uncertainty regarding near } \\
\text { future, misfit between } \\
\text { funding and service } \\
\text { responsibilities }\end{array}$ & $\begin{array}{c}\text { Initially low } \\
\text { Increasing over time } \\
\text { Low debt financing, healthy } \\
\text { financial reserves } \\
\text { /dependence on grants, } \\
\text { uncertainty regarding near } \\
\text { future, misfit between } \\
\text { funding and service } \\
\text { responsibilities }\end{array}$ & $\begin{array}{c}\text { Initially high } \\
\text { decreasing over time } \\
\text { Undiversified and unstable } \\
\text { revenue sources, } \\
\text { dependence on grants, high } \\
\text { debt financing, budget } \\
\text { deficits } \\
\text { /decreased dependence on } \\
\text { undiversified revenue } \\
\text { sources, decreasing debt, } \\
\text { budget stable }\end{array}$ & $\begin{array}{c}\text { Initially high } \\
\text { Decreasing over time } \\
\text { High debt financing, } \\
\text { reliance on but low control } \\
\text { of subsidiaries (liabilities), } \\
\text { one-off revenues, danger of } \\
\text { default, } \\
\text { /decreasing number of } \\
\text { subsidiaries, decreasing debt } \\
\text { and borrowing }\end{array}$ \\
\hline $\begin{array}{l}\text { Level and types of } \\
\text { anticipatory capacity } \\
\text { before the shock and } \\
\text { their /evolution over } \\
\text { time } * *\end{array}$ & $\begin{array}{c}\text { Initially high } \\
\text { stable over time } \\
\text { Medium-term financial } \\
\text { planning, risk assessment } \\
\text { and other monitoring tools }\end{array}$ & $\begin{array}{c}\text { Initially high } \\
\text { stable over time } \\
\text { Medium-term financial } \\
\text { planning, risk assessment } \\
\text { and other monitoring tools, } \\
\text { high environmental } \\
\text { awareness }\end{array}$ & $\begin{array}{c}\text { Initially low } \\
\text { Increasing over time } \\
\text { Weak medium term } \\
\text { financial planning, low } \\
\text { environmental (trends) and } \\
\text { self-awareness } \\
\text { Aong-term investment } \\
\text { planning, scenario analysis, } \\
\text { increasing self-awareness } \\
\end{array}$ & $\begin{array}{c}\text { Initially low } \\
\text { Increasing over time } \\
\text { Weak planning, weak } \\
\text { monitoring and control } \\
\text { /enhanced planning and } \\
\text { monitoring of expenditures }\end{array}$ \\
\hline $\begin{array}{l}\text { Levels ad types of } \\
\text { coping capacity**** }\end{array}$ & $\begin{array}{l}\text { Selective } \\
\text { Buffering: } \\
\text { Financial reserves, cost cuts, } \\
\text { increasing fees and charges, } \\
\text { virement, prioritization }\end{array}$ & $\begin{array}{c}\text { Selective } \\
\text { Buffering: } \\
\text { Financial reserves, cost cuts, } \\
\text { virement, prioritization, } \\
\text { over-programming (for } \\
\text { flexibility) } \\
\text { Adapting: } \\
\text { Invest to save, risk } \\
\text { management and } \\
\text { performance management, } \\
\text { re-balancing the budget, } \\
\text { partnerships, collegiate } \\
\text { planning } \\
\text { Transforming: } \\
\text {--- }\end{array}$ & $\begin{array}{c}\text { Selective } \\
\text { Buffering: } \\
\text { Cost cuts, increasing fees } \\
\text { and charges, deferring } \\
\text { investments and } \\
\text { maintenance, selling assets } \\
\text { (after needs assessment) } \\
\text { Adapting: } \\
\text { Task review, restructuring } \\
\text { services (mergers), } \\
\text { intercommunal urban } \\
\text { planning, proactive activities } \\
\text { in attracting businesses } \\
\text { Transforming: } \\
\text {--- }\end{array}$ & $\begin{array}{c}\text { Selective } \\
\text { Buffering: } \\
\text { Cost cuts, increasing taxes, } \\
\text { deferring investments, } \\
\text { prioritization } \\
\text { Adapting: } \\
\text { Networking with external } \\
\text { stakeholders for service } \\
\text { provision, re-organizations, } \\
\text { re-targeting service users, } \\
\text { task review, brake on debt } \\
\text { Transforming: } \\
\text {--- }\end{array}$ \\
\hline
\end{tabular}


Appendix Table 6: Pattern 4 and 5 - Contended and powerless fatalism.

\begin{tabular}{|c|c|c|c|c|}
\hline & A3 (Contended Fatalist) & A4 (Contended Fatalist) & I2 (Powerless Fatalist) & I3 (Powerless Fatalist) \\
\hline Budgetary position & Positive & Zero & Negative & Positive \\
\hline Volatility & High & High & High & High \\
\hline Context & $\begin{array}{c}\text { Institutional } \\
\text { Dependence of LGs on } \\
\text { central government transfers } \\
\text { and grants } \\
\text { Economic } \\
\text { Strong and diversified } \\
\text { economic base, landlocked } \\
\text { Socio-demographic } \\
\text { Decreasing population }\end{array}$ & $\begin{array}{c}\text { Institutional } \\
\text { Obligatory but non-binding } \\
\text { medium-term financial } \\
\text { planning } \\
\text { Economic } \\
\text { Strong and diversified } \\
\text { economic base } \\
\text { Socio-demographic } \\
\text { Population growth }\end{array}$ & $\begin{array}{c}\text { Institutional } \\
\text { Financial dependence of } \\
\text { LGs on central decisions } \\
\text { and grants } \\
\text { Economic } \\
\text { Housing bubble since the } \\
\text { beginning of the Millennium } \\
\text { Socio-demographic } \\
\text {--- }\end{array}$ & $\begin{array}{c}\text { Institutional } \\
\text { Financial dependence of } \\
\text { LGs on central decisions and } \\
\text { grants } \\
\text { Economic } \\
\text { Housing bubble since the } \\
\text { beginning of the Millennium } \\
\text { Socio-demographic }\end{array}$ \\
\hline Financial shocks & $\begin{array}{l}\text { Financial crisis, delayed } \\
\text { grant reduction }\end{array}$ & $\begin{array}{l}\text { Financial crisis, grant } \\
\text { reduction }\end{array}$ & $\begin{array}{l}\text { Grant reduction, decreasing } \\
\text { revenues from building } \\
\text { permits, increasing demand } \\
\text { for services, tightening of } \\
\text { fiscal targets, re- } \\
\text { centralization of decisions } \\
\text { and financial controls }\end{array}$ & $\begin{array}{l}\text { Grant reduction, increasing } \\
\text { demand for services, } \\
\text { tightening of fiscal targets, } \\
\text { re-centralization of decisions } \\
\text { and financial controls }\end{array}$ \\
\hline $\begin{array}{l}\text { Perceived } \\
\text { vulnerability levels } \\
\text { and sources before } \\
\text { the shock and their } \\
\text { /evolution over time } \\
*\end{array}$ & $\begin{array}{c}\text { Low/increasing } \\
\text { strong and diversified tax } \\
\text { revenues, assets as reserves } \\
\text { /high debt financing, foreign } \\
\text { currency loans, stagnation of } \\
\text { grants, weak networking and } \\
\text { partnerships with other LGs }\end{array}$ & $\begin{array}{c}\text { Low/increasing } \\
\text { growing, strong and } \\
\text { diversified tax revenues, } \\
\text { high debt financing } \\
\text { /no financial reserves, } \\
\text { unprepared for further } \\
\text { shocks }\end{array}$ & $\begin{array}{c}\text { High } \\
\text { /increasing } \\
\text { High debt financing, } \\
\text { reliance on but low control } \\
\text { of subsidiaries (liabilities), } \\
\text { doubtful liabilities, high } \\
\text { dependence on } \\
\text { intergovernmental grants } \\
\text { /unstable revenue sources }\end{array}$ & $\begin{array}{c}\text { High } \\
\text { /increasing } \\
\text { Slow revenues recovery, } \\
\text { weak managerial } \\
\text { responsiveness on financial } \\
\text { constraints } \\
\text { /unstable revenue sources }\end{array}$ \\
\hline $\begin{array}{l}\text { Level and types of } \\
\text { anticipatory capacity } \\
\text { before the shock and } \\
\text { their /evolution over } \\
\text { time ** }\end{array}$ & $\begin{array}{c}\text { Low/ } \\
\text { increasing } \\
\text { Weak medium-term } \\
\text { financial planning } \\
\text { /anticipated approval of } \\
\text { supplementary budget, } \\
\text { enhanced financial } \\
\text { monitoring }\end{array}$ & $\begin{array}{c}\text { Low } \\
\text { /increasing } \\
\text { Weak medium-term } \\
\text { financial planning, constant } \\
\text { use of re-budgeting, implicit } \\
\text { and informal planning } \\
\text { /"Crisis management team" } \\
\text { of political and } \\
\text { administrative actors }\end{array}$ & $\begin{array}{c}\text { Low/ } \\
\text { increasing } \\
\text { Weak planning, and } \\
\text { monitoring processes, } \\
\text { limited information } \\
\text { exchange } \\
\text { /monitoring of revenues } \\
\text { collection }\end{array}$ & $\begin{array}{c}\text { Low/ } \\
\text { increasing } \\
\text { Weak planning and } \\
\text { monitoring processes, low } \\
\text { awareness } \\
\text { /monitoring of revenues } \\
\text { collection and of balanced } \\
\text { budget }\end{array}$ \\
\hline $\begin{array}{l}\text { Levels ad types of } \\
\text { coping capacity*** }\end{array}$ & $\begin{array}{c}\text { Limited } \\
\text { Buffering: } \\
\text { Cost cuts, increase in fees } \\
\text { and charges, deferring } \\
\text { investments and } \\
\text { expenditures, increase in } \\
\text { debt (loans) } \\
\text { Adapting: } \\
\text { Urban planning } \\
\text { Transforming: } \\
---\end{array}$ & $\begin{array}{c}\text { Limited } \\
\text { Buffering: } \\
\text { Moratorium on debt } \\
\text { repayment, cost cuts, } \\
\text { deferring investments, } \\
\text { centralization of purchasing } \\
\text { Adapting: } \\
--- \\
\text { Transforming: } \\
---\end{array}$ & $\begin{array}{c}\text { Limited } \\
\text { Buffering: } \\
\text { Selling assets, cancellation } \\
\text { of doubtful liabilities }\end{array}$ & $\begin{array}{c}\text { Limited } \\
\text { Buffering: } \\
\text { Financial reserves (one-off } \\
\text { transactions with the } \\
\text { subsidiary company), cost } \\
\text { cuts, deferring investments, } \\
\text { prioritization of expenditures } \\
\text { Adapting: } \\
--- \\
\text { Transforming: } \\
---\end{array}$ \\
\hline
\end{tabular}

